\title{
Las culturas del neolítico-calcolítico en Andalucía Oriental
}

\author{
manuel Pellicer Catalán *
}

En 1986 el profesor M. Otte, de la Universidad de Lieja (Bélgica), programó un gran atlas sobre el Neolítico de Europa, incluyendo el Calcolíticocampaniforme, para poner al día la arqueología material, la distribución de yacimientos y la cronología radiocarbónica calibrada de los horizontes culturales prehistóricos, desde el vI a principios del II milenio a. C.

En principio se encomendó la redacción del neolítico-calcolítico de Andalucía en general a los profesores P. Acosta y M. Pellicer, de la Universidad de Sevilla, trabajo que quedó finalizado, según meras normas fijadas por el profesor M. Otte, en 1987. Al hacerse cargo de la dirección del atlas el profesor J. Guilaine, se modificaron los esquemas y se consideró conveniente ajividir el trabajo en dos partes, sobre Andalucía Occidental y sobre Andalucía Oriental, redactadas por los profesores $\mathrm{P}$. Acosta y $\mathrm{M}$. Pellicer respectivamente. La nueva estructura nos obligó a rehacer los trabajos de nuevo, por lo que hemos optado por publicarlos en España.

El esquema de los trabajos sigue la pauta propuesta para el Atlas del Neolítico de Europa, contemplando esencialmente la arqueología material, la evidencia arqueológica y la objetividad de la innovación tecnológica, prescindiendo de los otros modelos o aspectos, muy en boga en la arqueología procesual, como puecien ser los ecosistemas, la complejidad social, la escala y demografía de los sistemas y la integración políticoeconómica, presentando, no obstante, el aspecto económico de cada horizonte en función de la fauna, botánica y tecnología, sin penetrar intencionadamente en modelos socio-políticos, excesivamente aventurados y subjetivos, definidos o explicados por la peligrosa deducción.

* Catedrático Emérito. Universidad de Sevilla. 
Tratándose de un atlas, se ha puesto especial énfasis en la descripción tipológica del registro arqueológico, del hábitat y enterramiento, acompañada de una parte gráfica, en la distribución y carácter de los yacimientos por horizontes culturales mediante cinco mapas. La cronología absoluta se ha expresado en cinco tablas, correspondientes a cada uno de los horizontes, tripartitos en el neolítico y bipartitos en el calcolítico, y la cronología relativa se ha deducido en función de las estratigrafías, lamentablemente muy escasas en Andalucía Oriental.

Naturalmente la exigua extensión del trabajo no permite una recopilación exhaustiva de lo que se conoce sobre la emergencia de las sociedades productoras, pero no dudamos de que, pese a sus limitaciones, la exposición puede servir de útil guía e interesante ayuda para contemplar el panorama del neolítico-calcolítico de Andalucía Oriental.

\section{NEÓLITICO ANTIGUO}

\section{Región considerada}

Prescindiendo de la delimitación de las cuatro provincias que constituyen Andalucía Oriental (Almería, Jaén, Granada y Málaga), es preferible seguir un criterio geográfico, en función de las cuencas fluviales y de la orografía, criterio que coíncide más o menos con las facies culturales. En este sentido y considerando que los accidentes geográficos discurren diagonalmente de noreste a suroeste, Andalucía oriental podría dividirse en comarcas o zonas:

a) La Sierra Morena, al norte del Guadalquivir desde Beas de Segura hasta Andújar.

b) El alto Guadalquivir, desde Segura de la Sierra hasta Marmolejo.

c) La cordillera subbética y campiña giennense, desde las Sierras de Segura y Cazorla hasta Castillo de Locubín.

d) La Altiplanicie granadina y alto Genil, desde Huéscar a Loja.

e) El Sistema Penibético con su vertiente sur costera, desde Lubrín hasta Zafarraya y el río Vélez.

f) Las cuencas de los ríos de Almería sur-oriental (Almanzora, Antas, Aguas y Andarax).

\section{Nombre de la cultura}

La terminología más adecuada sería neolítico antiguo de la cerámica impresa o cardial de tipo Carigüela, aunque no sea una característica ge- 
neral, no obstante sigue denominándosele impropiamente cultura de las cuevas. El nombre de neolítico hispano-mauritano cayó en desuso junto con un difusionismo ilusorio.

\section{Datación}

Se superpone, en ocasiones, al sustrato epipaleolítico microlaminar, como sucede en las cuevas de Nerja y del Nacimiento. En los otros yacimientos conocidos el neolítico aparece «ex novo». La cronología radiocarbónica, calibrada, se ha obtenido en la cueva de Nerja y del Nacimiento en la primera mitad del vı milenio a. C., y, sin calibrar, en la cueva de los Murciélagos de Albuñol, de mediados del vı milenio a. C., por lo que, si su origen es sustancialmente levantino, en este círculo habría que considerar una cronología más alta.

\section{NEOLÍTICO ANTIGUO}

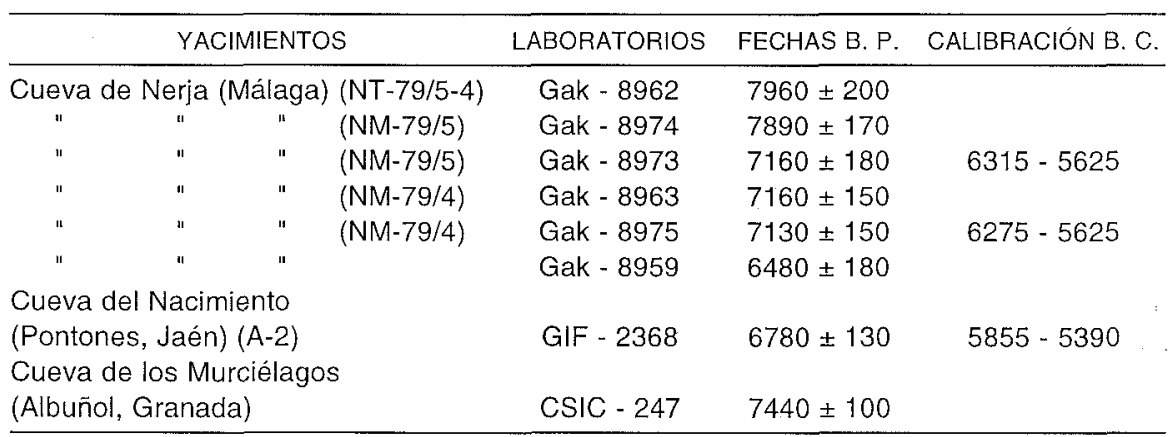

\section{Extensión geográfica}

La extensión geográfica no está suficientemente determinada a causa de la irregularidad y grado de intensidad de las prospecciones, preferentemente dirigidas hacia el estudio del calcolítico y del bronce. Se tienen localizados en este área más de una veintena de yacimientos, de los que la quinta parte corresponden a poblados de superficie. En general, el neolítico antiguo se extiende por la costa, en cuevas, como Nerja, Capitán, Murciélagos de Albuñol o en superficie, como el Peñón de Salobreña y Cíavieja. Más densamente se extiende por el centro de la región, cuyo yacimiento paradigmático es la cueva de la Carigüela de Piñar, con exten- 
siones por el río Cacín hasta la comarca de Antequera (cueva de las Goteras) y hacia el norte y noreste (cuevas del Nacimiento, Valdecuevas, de Ambrosio y Cerro de las Ánimas) con presencia de cerámica cardial hacia el sur, con mucha menos intensidad que en Levante, y cerámica a la almagra, de evidente influencia de Andalucía occidental (figura 1).

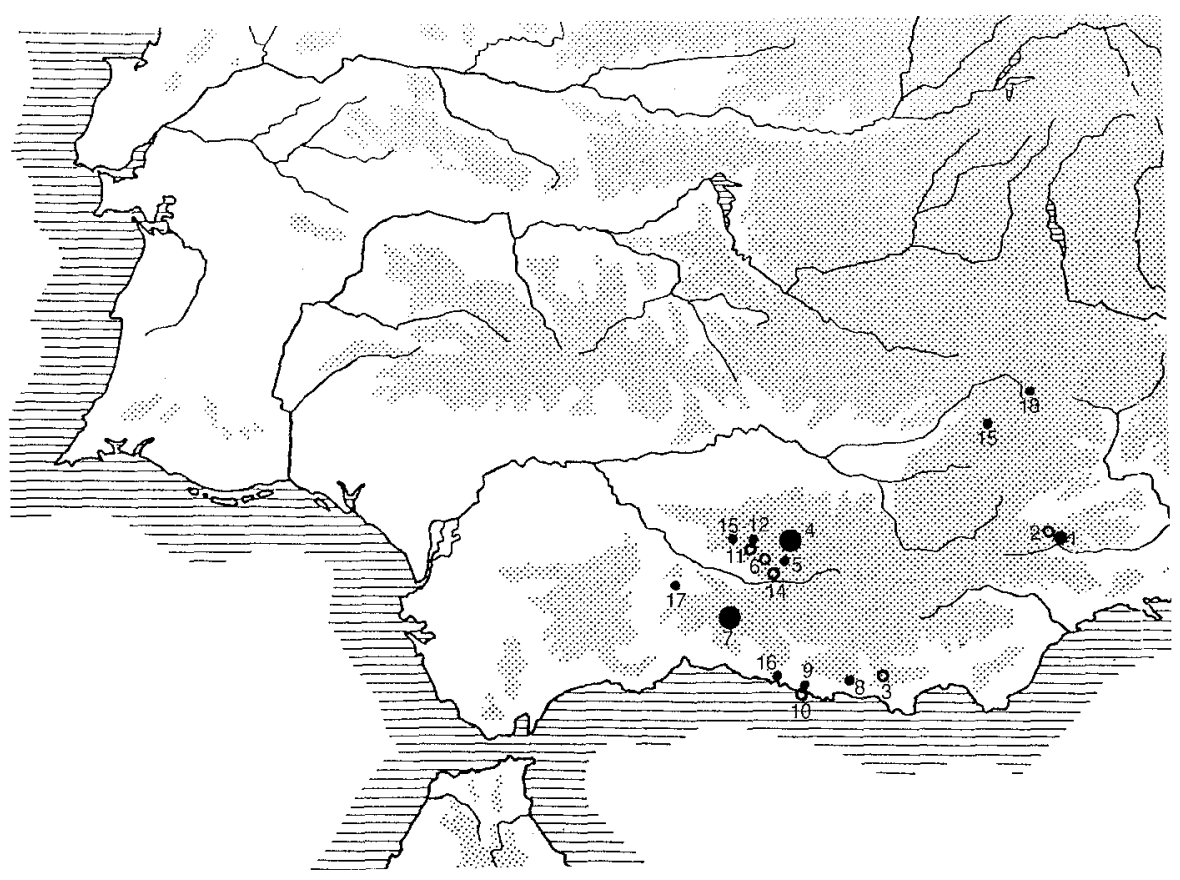

Fig. 1. Neolítico Antiguo (Fines vi milenio - Primera mitad del v milenio) Hábitat: Cueva $(\bullet)$. Conjunto de cuevas (๑). Poblado de superficie (0).

1. Cueva de Ambrosio (Vélez Blanco, Almería). 2. Cerro de las Ánimas (Vélez Blanco, Almería). 3. Cíavieja (Dalías, Almeria). 4. Cuevas de Pínar (Granada): Carigüela, Ventana. 5. Cueva de las Majolicas (Alfacar, Granada). 6. La Molaina (Pinos Puente, Granada). 7. Cuevas de Cacín (Alhama de Granada). 8. Cueva de los Murciélagos (Albuñol, Granada). 9. Cueva del Capitán (Salobreña, Granada). 10. El Peñón (Salobreña, Granada). 11. Las Catorce Fanegas (Moclín, Granada). 12. Cueva de Malalmuerzo (Moclín, Granada). 13. Cueva de las Cabras (Montefrío, Granada). 14. Chaucina (Granada). 15. Valdecuevas (Cazorla, Jaén). 16. Cueva de Nerja (Málaga). 17. Cueva de las Goteras (Mollina, Málaga). 18. Cueva del Nacimiento (Pontones, Jaén).

\section{Cerámica}

En las primeras cerámicas destacan las de alta calidad, tanto con decoración cardial como con técnica a la almagra, cuyo grado de evolución sugiere que se han impuesto ya formadas, desde Levante las cardiales y 
desde Andalucía occidental las almagras. Son dignos de observación los fragmentos de cerámica sin cocer con improntas de cestería hallados en el epipaleolítico de Nerja. Si la cerámica a la almagra se extiende por toda la región, la cardial está ausente en los macizos montañosos giennenses subbéticos y en Sierra Morena.

Las formas cerámicas se reducen a cuencos de borde entrante, peraltados, semiesféricos, vasos globulares con gollete y ovoides, bordes ondulados, con elementos de prehensión de tipo mamelón perforado o no, lengüeta recta o realzada, asas de cinta, multiforadas, de túnel verticales $u$ horizontales.

Entre las técnicas decorativas destacan las plásticas con cordones, generalmente con impresiones digitales o instrumentales, las incisas, acanaladas, cardiales y cardialoides efectuadas con matrices dentadas, bordes dentados, etc. La decoración cardial con el natis de la concha sólo aparece en la cueva de Malalmuerzo (Moclín), de indudable influencia levantina. Los motivos decorativos, sumamente variados, representan líneas quebradas paralelas, reticulados, espigas horizontales y grandes composiciones geométricas paralelas, rectangulares, curvas y triangulares, efectuadas con la técnica cardial o cardialoide. En ocasiones, los motivos se resaltan con incrustación de pasta roja (figura 2).

\section{Industria lítica}

La industria lítica tallada, poco diversificada, es de tipo microlaminar y de tradición epipaleolítica, con alto porcentaje de hojas, hojitas y lascas retocadas y convertidas en raspadores, buriles, bordes abatidos, denticulados, fracturas, crestas, estando presentes, en escaso porcentaje, los geométricos, especialmente los trapezoidales. Presentes, aunque poco abundantes, son los pulimentados, como hachas, hachitas y azuelas. Los elementos de molienda, como molinos planos y naviformes, moletas y machacadores, suelen estar manchados de ocre, no utilizados para cereales.

\section{Industria del hueso}

La industria ósea, más frecuente y diversificada que en el epipaleolítico y menos que en el neolítico medio, se reduce a punzones sobre metápodos de ovicápridos, tanto biselados, los más abundantes, como de media caña, estando presentes las espátulas. 

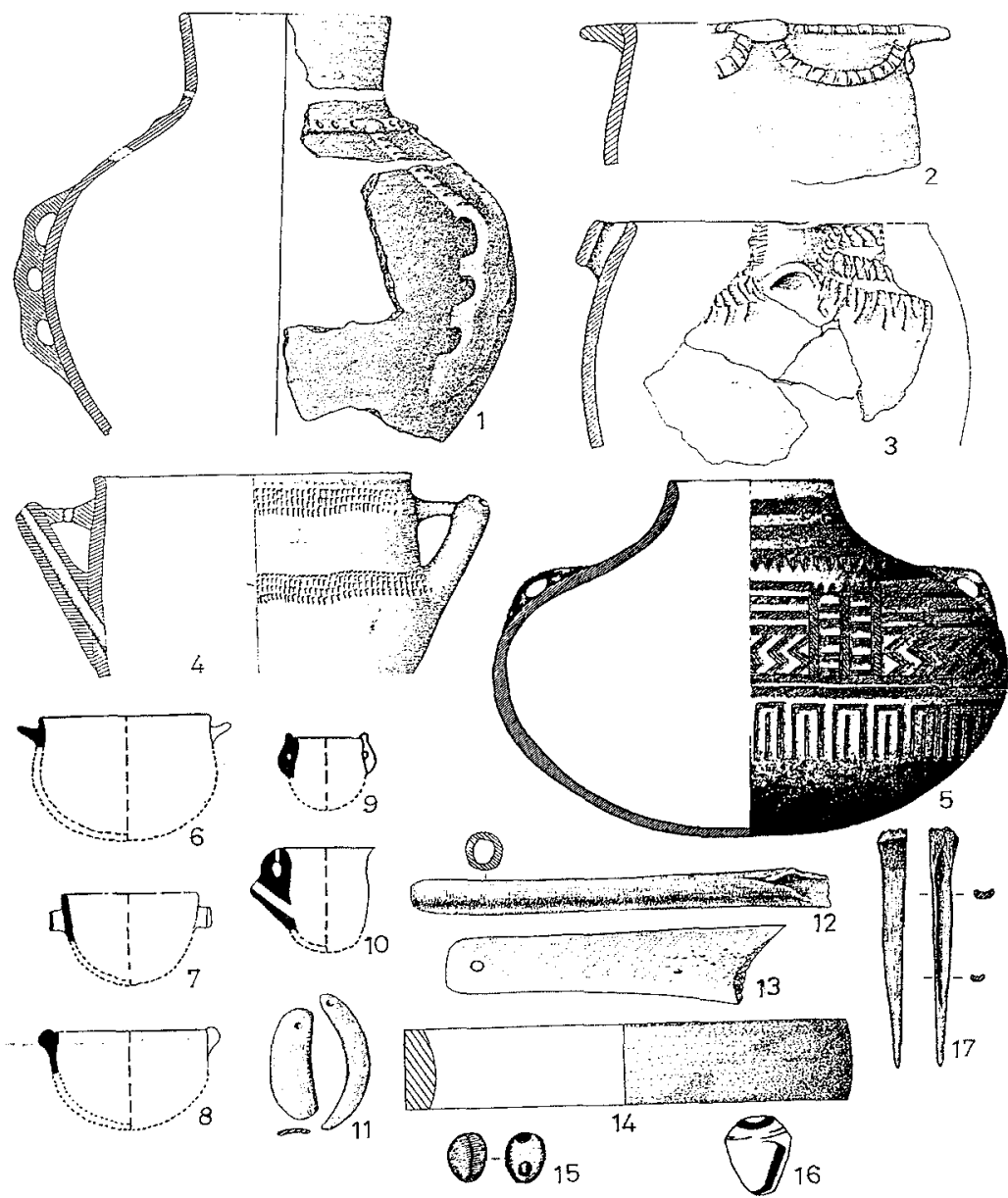

Fig. 2. Neolítico Antiguo.

1. Vaso globular con gollete, asas multiforadas y cordones. 2. Vaso ovoide, mamelones y guirnaldas de cordones. 3 . Vaso ovoide, asas de túnel verticales y decoración cardial. 4. Vaso cilíndrico, asa de pitorro y decoración cardialoide. 5. Vaso globular achatado, gollete y decoración cardialoide. 6. Vaso semiesférico, mamelones. 7. Vaso semiesférico, asas de túnel verticales. 8 . Vaso semiesférico, mamelones verticales. 9. Vaso de perfil en S, asas de puente con apéndice. 10. Vaso de perfil en $S$, asa de pitorro. 11. Colgantes de concha. 12. Tubo de hueso. 13. Colgante-espátula de inueso. 14. Brazalete cilíndrico de mármol. 15. Cypraea perforada. 16. Conus perforado. 17. Punzón de hueso cortado en media caña. Procedencia:

1-4: Cueva de Nerja (Málaga). 5-10 y 13: Cueva de la Carigüela (Pínar, Granada). 11 y 17: Cueva del Agua de Prado Negro (Iznalloz, Granada). 12: Cueva CV-3 (Cogollos Vega, Granada). 14: Cueva de la Ventana (Píñar, Granada). 15 y 16: Cueva del Coquino (Loja, Granada).

1-4: según M. Pellicer y P. Acosta. 5-10 y 13: según M. Pellicer y M. ${ }^{a}$ S. Navarrete. 11 , 12, 14-16: según M. S. Terual. 17: según M. S. Navarrete y J. CaPel. 


\section{Adornos}

Los elementos decorativos personales no tienen la diversidad ni la abundancia del Levante, iniciándose ya los brazaletes de calcita o mármol blanco, todavía sin decorar, y más débilmente los finos, de corona circular, de pizarra o mármol negro. Aparecen los colgantes de hueso muy simples y los anillos, acompañados de conchas marinas perforadas de especies columbella, conus, dentalium y patella.

\section{Economía}

Los restos predominantes, exponente de la economía, son mayormente la fauna de mamíferos, combinándose en la costa con malacofauna e ictiofauna. Dados los escasos análisis de fauna efectuados, nos remitimos singularmente al ejemplo de la cueva de Nerja y a algunos datos de las cuevas del Nacimiento y de la Carigüela de Piñar. En Nerja se estudió conjuntamente la fauna del neolítico antiguo y medio, con un resultado de $37 \%$ de ovicápridos, $31 \%$ de bóvidos y $10 \%$ de cerdo. La malacofauna alcanza en el neolítico antiguo el $45 \%$ del total de la secuencia neolítico-calcolítico, que, distribuído en especies, tenemos $2 \%$ de iberus alonensis, $33 \%$ de patella, $20 \%$ de monodonta, $12 \%$ de tahís, $25 \%$ de mytilus, $4 \%$ de melanopsis y $4 \%$ de varios.

En la Carigüela la fauna doméstica presenta un cuadro decreciente desde el ovicáprido hasta el bóvido y cerdo, siendo más abundante la fauna salvaje, en el siguiente orden decreciente: ciervo, jabalí, caballo, capra hispánica, conejo, liebre. En la cueva del Nacimiento las especies documentadas son la oveja, cabra, cerdo, capra hispánica, ciervo, jabalí y caballo.

Respecto a la agricultura, existen serias dudas sobre su aparición en el neolítico antiguo. En las excavaciones 1959/60 en la Carigüela no se detectó presencia de cereales, pero en las posteriores parece que fue localizado un silo en el nivel 16 con cereales. En Nerja la dieta alimenticia vegetal está representada por piñones y bellotas.

\section{Ritos funerarios}

En la cueva de Nerja los enterramientos se efectúan en el mismo hábitat, estando los individuos en posición encogida y sin ajuar aparente. Los datos de la cueva de los Murciélagos de Albuñol son inexpresivos a causa del saqueo del yacimiento y por el horizonte avanzado del famoso enterramiento colectivo. 


\section{ARTE RUPESTRE}

Resulta arduo colocar con seguridad parte del arte rupestre esquemático en el neolítico antiguo, pero existen cerámicas con decoración cardial o cardialoide representando antropomorfos (Prado Negro). En el estado actual de conocimientos parece correspondiente al neolítico antiguo el llamado ciclo seminaturalista de la parte oriental de Jaén, en la Sierra de Quesada (Cueva del Encajero, Arroyo de Tíscar, Abrigo de Manolo Vallejo, Las Herreras, Río Frío, Collado del Guijarral, etc.), en la Sierra de Segura y Despeñaperros (Canjorro de Peñarrubia, Prado del Azogue, Tabla del Pochino) y en Almería septentrional (Cueva de los Letreros, Gabal de Vélez Blanco). Los motivos, pintados en rojo, sobre las paredes de los abrigos rocosos se reducen principalmente a cápridos, cérvidos y antropomorfos, formando conjuntos más o menos hilvanados o aislados. Se trata de un arte rupestre muy extendido por Sierra Morena y Cordilleras Béticas.

\section{Hábitat}

El tipo de hábitat adquiere las modalidades de cueva, abrigo y de superficie. Hasta hace unos años solamente se tenía noticia de yacimientos en cueva, de aquí la denominación de cultura de las cuevas, pero conforme las prospecciones han ido intensificándose, se ha constatado la vivienda también en abrigos y al aire libre. La difícil localización de los yacimientos de superficie, muy erosionados o colmatados por aportes sedimentarios, contribuye al exiguo número conocido. Solamente disponemos de las estratigrafías de cuatro yacimientos con resultados aprovechables, cueva de Nerja, de la Carigüela, del Capitán y del Nacimiento. La ausencia de excavaciones adecuadas en yacimientos de superficie, como el Llano de las Canteras, L.a Molaina, Las Catorce Fanegas, El Cerro de las Ánimas y Cíavieja, no nos ha permitido obtener datos sobre la estructura del hábitat en general o de las viviendas. Según el tamaño de estos yacimientos, comprendido entre 0,6 y 1 hectárea, la demografía de cada uno no pasaría de los 100 habitantes.

\section{Yacimientos}

Se conoce la situación de más de una veintena de yacimientos, de los que la quinta parte son de superficie, correspondientes al neolítico antiguo 
con cerámicas impresas y, en algunos casos, cardiales. Los yacirnientos en cueva se distribuyen en tres círculos, correspondiendo al de la costa las cuevas de Nerja, Capitán y Murciélagos de Albuñol y los yacimientos al aire libre del Peñón de Salobreña y de Cíavieja. Al círculo central granadino se adscriben las cuevas de la Carigüela, las de Alhama de Granada en el río Cacín, las Majolicas y los yacimientos de superficie de la Molaina y las Catorce Fanegas. Al círculo septentrional de las Sierras de Jaén y Almería corresponden las Cuevas del Nacimiento, Valdecuevas y de Ambrosio y el yacimiento de superficie del Cerro de las Ánimas.

\section{Estadios}

En el neolítico antiguo se ha observado una evolución en función de las estratigrafías de las cuevas de Nerja y de la Carigüela, de la cronología radiocarbónica y de la tipología tecnológica, centrada primordialmente en la cerámica, habiéndose podido distinguir dos fases, en cierta medida, artificiales. A la fase A del neolítico antiguo de Nerja correspondería el nivel 10 del corte NT-82, el 10B del NM-80 B y el 6 del NM-80A, con una cronología radiocarbónica entre 5500 y 5000 a. C. Esta fase $A$ en la Carigüela está representada por los niveles 16-14, y la fase B por los niveles 13-12, con una cronología, al parecer, ligeramente posterior a la de Nerja y a la de Andalucía occidental.

La fase $A$ del neolítico antiguo de Nerja correspondería al nivel 10 (NT$82), 10 \mathrm{~B}(\mathrm{NM}-80 \mathrm{~B})$ y 6 (NM-84 A), con una cronología que ocuparía casi todo el VI milenio. La fase $B$ del neolítico antiguo de Nerja viene determinada por el nivel 9 del corte NT-82, por el $10 \mathrm{~A}$ del NM-80 B y 5 del NM-84 A, con una cronología de la primera mitad del v milenio a.C., correspondiéndose con los niveles 13-12 de la Carigüela.

\section{Facies regionales}

Por los datos disponibles, Andalucía oriental podría dividirse en cinco facies regionales del neolítico antiguo, siempre con reservas y en espera de una documentación más precisa, que, enumeradas de noreste a suroeste, serían: A) Las sierras del norte y noreste, de Segura, de las Estancias y Sierra Morena oriental, cuyos yacimientos más significativos son las cuevas del Nacimiento, Valdecuevas y Ambrosio, con cerámica impresa no cardial. B) Altiplanicies granadinas y macizo montañoso del sur de Jaén (cueva de la Carigüela), con cerámicas impresas, cardiales y 
a la almagra. c) La depresión del Genil y Cacín, con los mismos tipos cerámicos, cuyo principal exponente son las cuevas de Alhama de Granada. d) La parte oriental de Almería, extendida por las cuencas medias y bajas de los ríos Andarax y Almanzora, sin yacimientos aparentes. e) La zona costera oriental de Málaga y de Granada, con las cuevas de Nerja, Capitán de Salobreña y Murciélagos de Albuñol, con simple presencia de cerámica cardial y abundancia de impresa, relieves y a la almagra.

\section{NEOLITICO MEDIO}

Región considerada

Provincias de Jaén, Granada, Almería y parte oriental de Málaga costa, comarcas ya enunciadas en el neolítico antiguo.

\section{Nombre de la cultura}

En la nomenclatura antigua correspondería igualmente a la cultura de las cuevas. En los años cuarenta y cincuenta se consideró continuación del neolítico hispano-mauritano o neolítico I. La terminología de epicardial es inaplicable a la mayor parte de la región considerada, porque sólo en la facies del altiplano granadino existe bien representada la fase anterior de la cerámica cardial, ya que, hacia el norte, esta cerámica no se documenta y, hacia el sur, representa un simple episodio, incapaz de dar paso a un epicardial. Por los yacimientos excavados estratigráficamente, cabría la denominación de neolítico de la cerámica incisa y de plenitud de la cerámica a la almagra, ambas características.

\section{Datación}

El neolítico medio ha podido determinarse estratigráficamente entre el antiguo y el final en las cuevas de Nerja, Carigüela y Capitán. De Nerja existen varias fechas radiocarbónicas, que, no calibradas, apuntan al $v$ milenio y a principios del $\mathrm{v}$, por lo que sería plausible delimitar la fase entre el 4500 y el 3500 a. C. En la cueva de la Carigüela, sin fechas radiocarbónicas, el neolítico medio corresponde a los niveles 11-7, según la última revisión. La cueva del Toro de Antequera con una estratigrafía iniciada en el neolítico medio, estrato IV, ha dado la fecha sin calibrar del 
$4450 \pm 280$ a. C. La cueva del Nacimiento ha entregado para este momento la fecha de $3990 \pm 110$ a. C., que, calibrada, corresponde a $5065 \pm$ 4715 a. C. La cueva de los Murciélagos de Albuñol ha proporcionado dos fechas, una, sin calibrar, de $3450 \pm 80$ a. C. y otra, calibrada, del $4415 \pm$ 3955 a. C. En la cueva del Capitán, el neolítico medio corresponde al nivel 3 , y el estrato inferior de los Castillejos de Montefrío (VI B-A = fase I), se incluiría en un neolítico medio, hacia el 4000 - 3500 a. C.

\section{NEOLÍTICO MEDIO}

\begin{tabular}{|c|c|c|c|}
\hline YACIMIENTOS & LABORATORIOS & FECHAS B. P. & CALIBRACIÓN B. C. \\
\hline Cueva del Toro (Antequera, Málaga) (IV) & & $6400 \pm 280$ & \\
\hline Cueva de Nerja (Málaga) (NT-82/9) & Ugra - 261 & $6200 \pm 100$ & $5360-4925$ \\
\hline$" \quad " \quad(N M-79 / 2)$ & Gak - 8969 & $5790 \pm 140$ & $4925-4525$ \\
\hline Cueva del Nacimiento (Pontones, Jaén) & ) GIF - 5421 & $5940 \pm 110$ & $5065-4715$ \\
\hline
\end{tabular}

\section{Extensión geográfica}

Sensiblemente el neolítico medio se extiende como el antiguo, pero con más intensidad, significando la eclosión de la cultura. A falta de investigaciones pertinentes, no es posible, por el momento, hacer más precisiones geográficas, excepto enumerar los yacimientos (figura 3 ).

\section{Cerámica}

Es el horizonte de las cerámicas incisas, acanaladas y a la almagra, con notable aumento de los vasos con decoración plástica. La cerámica a la almagra tiene más pes̀o específico hacia la parte occidental, descendiendo notablemente la especie impresa de tradición cardial o cardialoide. Las formas cerámicas siguen el ritmo iniciado en el neolítico antiguo, con síntomas de evolución, con cuencos más profundos, cilíndricos, cerrados y ovoides, con los bordes más indicados que preludian los perfiles en $S$ y $Z$ del neolítico final y con inicios de débiles carenas con paredes entrantes cóncavas, persistiendo con profusión las formas globulares con gollete. Están presentes las bases planas, los bordes ondulados y decorados con resaltes y mamelones. Los elementos de prehensión, prosiguiendo los tipos anteriores, se diversifican con variadas especies de mamelones simples, de lengüeta horizontal y realzada, con o sin perforación para cuerda, asas de puente, de túnel y de cinta. Es el apogeo de las largas asas 


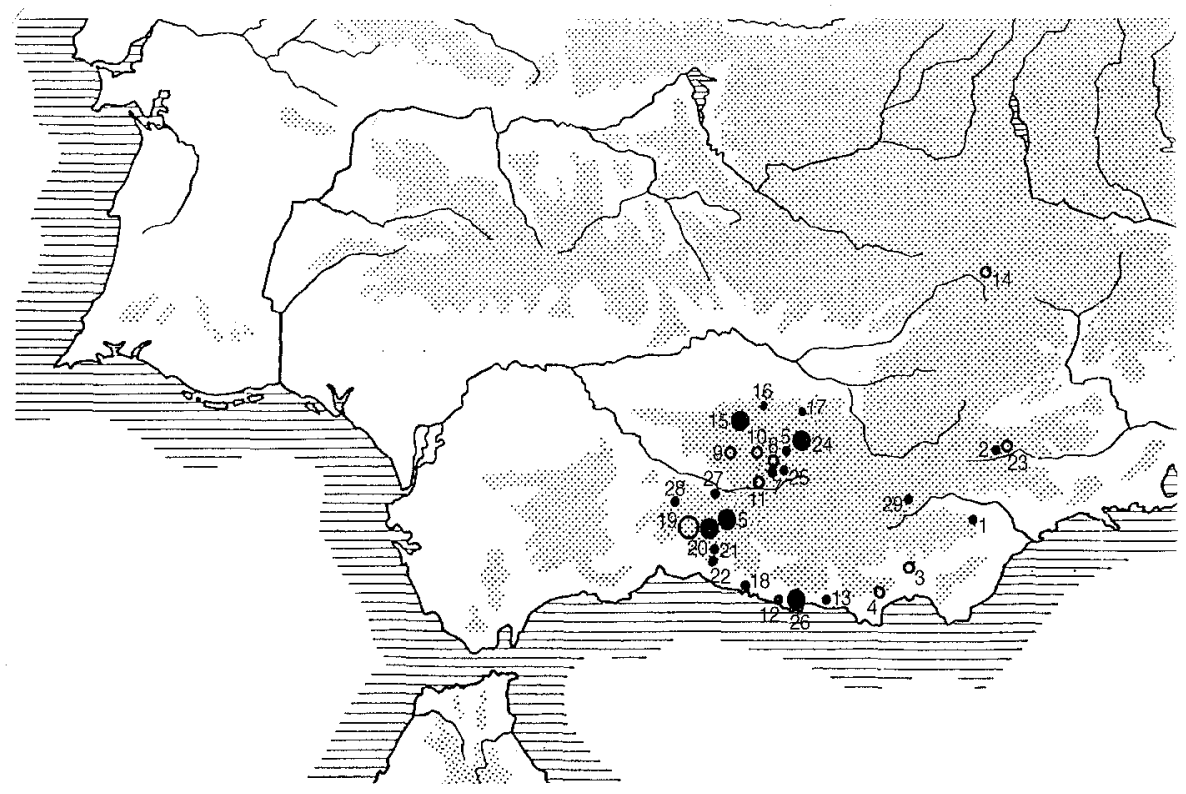

Fig. 3. Neolítico Medio (Segunda mitad del $v$ milenio - Primera mitad del IV milenio)

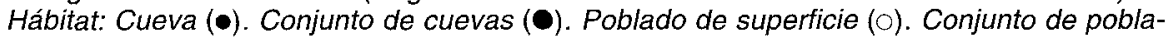
dos de superficie (O)

1. Cueva del Castillico (Cóbdar, Almería). 2. Cueva de Ambrosio (Vélez Blanco, Almería). 3. Cerro de la Chinchilla (Rioja, Almería). 4. Cíavieja (Dálias, Almería). 5. Cuevas de Pínar (Granada): Carigüela, Ventana. 6. Cuevas de Alhama de Granada: Mujer. Agua. Los Molinos. 7. Cueva de las Majolicas (Alfacar, Granada). 8. Llano de las Canteras (Alfacar, Granada). 9. Peña de los Gitanos (Montefrío, Granada). 10. Las Catorce Fanegas (Moclín, Granada). 11. La Molaina (Pinos Puente, Granada). 12. Cueva del Capitán (Salobreña, Granada). 13. Cueva de los Murciélagos (Albuñol, Granada). 14. Hornos de Segura (Jaén). 15. Cuevas de Castillo de Locubín (Jaén): Chatarra. Plato. Murcielaguina. 16. Cueva del Canjorro (Otiñar, Jaén). 17. Cueva de Guadalijar (Huelma, Jaén). 18. Cueva de Nérja (Málaga). 19. Conjunto del Tajo de Gomer (Ríogordo, Málaga). 20. Cuevas de Alcaucín (Málaga): Zafarraya. Los Guaicos. Abrigo del Espino. 21. Cueva de la Gájara (Canillas del Aceituno, Málaga). 22. Cueva del Puerto (Cómpeta, Málaga). 23. Cerro de las Ánimas (Vélez Blanco, Almería). 24. Cueva del Agua de Prado Negro (Iznalloz, Granada). 25. Cueva de Cogollos Vega (Granada). 26. Cueva de las Campañas (Gualchos, Granada). 27. Cueva del Coquinto (Loja, Granada). 28. Cueva de las Goteras (Mollina, Málaga). 29. Cueva de Caniles de Baza (Granada).

múltiples o multiforadas, de las llamadas asas de pitorro o vertedero y de las asas de codo con apéndice superior, haciendo su aparición la cuchara.

Las técnicas decorativas igualmente se diversifican, con profusión de la especie a la almagra, que admite cualquier otra técnica. Se impone por antonomasia la técnica de la incisión y del acanalado con variados motivos y los vasos plásticos con cordones, decorados con impresiones, tienen es- 
pecial aceptación. Aparece la técnica del grabado o esgrafiado y muy débilmente los motivos pintados, estampillados y puntillados. La incrustación de pasta roja sobre incisiones o impresiones adquiere altos procentajes, especialmente en la parte occidental de la región. La técnica impresa pierde su protagonismo anterior sustituída por la cardialoide e incisa. Los motivos decorativos adquieren una riqueza inusitada a base de los más variados geometrismos rectilíneos de paralelas, flejos, ramiformes, escaliformes o tectiformes, metopas, reticulados y de geometrismos curvilíneos como festones, rellenos de otros motivos, haciendo su aparición los esteliformes (Nerja, Carigüela, Prado Negro, Carburero, Mujer) y algún antropomorfo con técnica incisa o cardialoide (Prado Negro). Muchas decoraciones parten de las asas y, como elemento característico, es frecuente el borde dentado (figura 4).

\section{Industria lítica}

Prosigue la técnica laminar menos diversificada con láminas, laminitas, lascas y lasquitas, generalmente retocadas, con tipologías de bordes abatidos, muescas, denticulados, fracturas, tranchets, raspadores simples, además de los núcleos y restos de talla, teniendo débil presencia los geométricos trapezoidales.

El aumento de los pulimentados y molinos o piezas de molturación es patente, los primeros con hachas, hachitas y azuelas y los segundos con formas planas y naviformes.

\section{Industria del hueso}

Adquiere un especial volumen, tanto respeto al neolítico antiguo como al final, sobresaliendo los punzones en metápodos de ovicápridos con punta en bisel, seguidos, en menor proporción, por los punzones sobre huesos largos cortados longitudinalmente. Están presentes, en pequeño porcentaje, las espátulas y tubitos óseos, como adornos o elementos de enmangue.

\section{Adornos}

Los elementos de adorno personal llegan a su apogeo, siguiendo tipos anteriores, pero evolucionados y diversificados. Definitivamente se ponen 

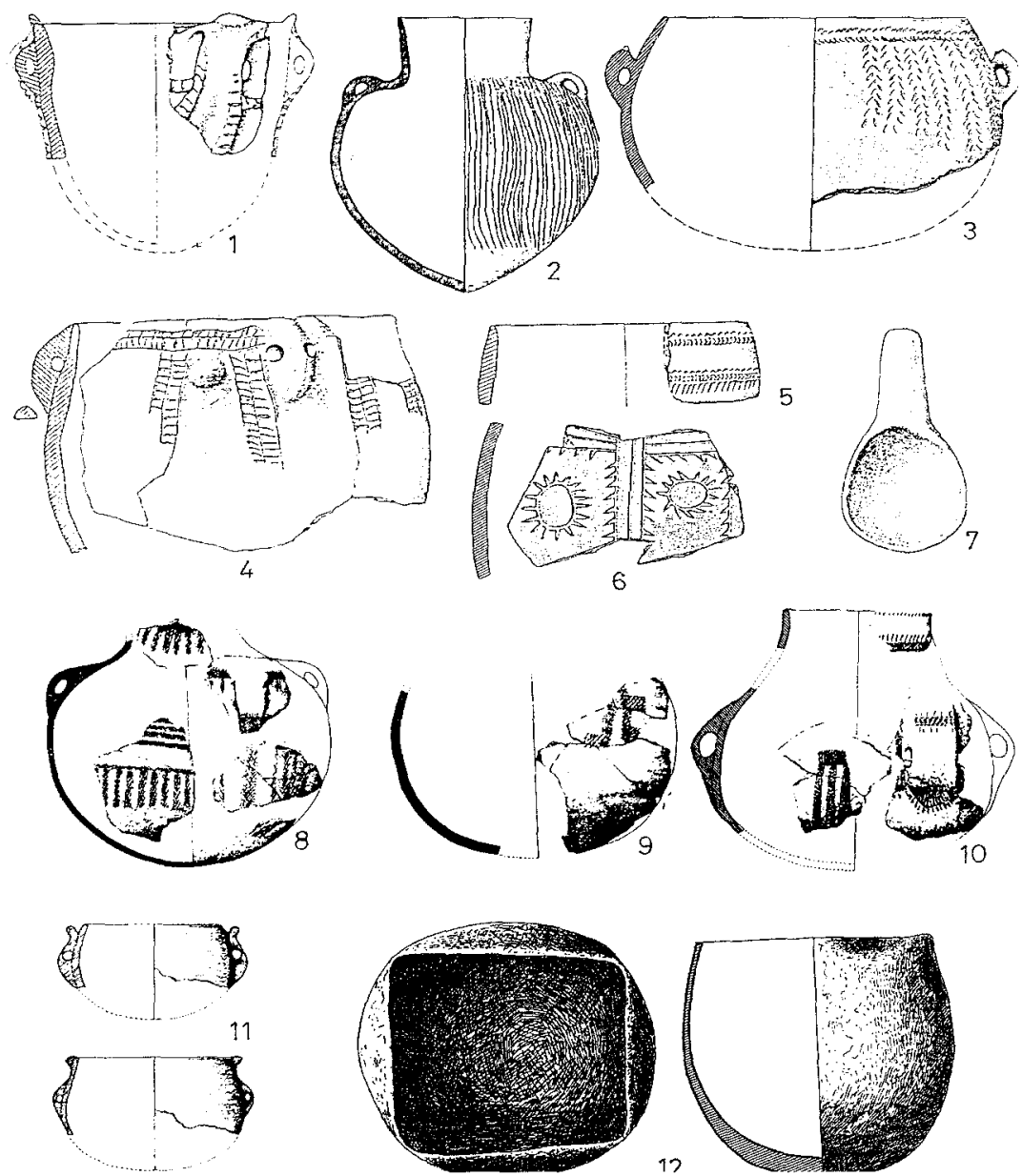

Fig. 4. Neolítico Medio.

1. Vaso semiovoide, asas con apéndice y cordones. 2. Vaso ovoide, gollete y asas de cinta, decoración incisa. 3. Vaso semiesférico, asas de nariz, decoración impresa de trazos. 4. Vaso ovide, asas de puente, decoración de escaliformes incisos e impresos. 5 . Vaso con decoración impresa. 6 . Fragmento cerámico con decoración incisa-impresa de esteliformes en metopas. 7. Cuchara de cerámica. 8. Vaso globular con gollete, asas de puente, decoración de reticulados incisos. 9. Vaso globular con decoración cardialoide de antropomorfo. 10. Vaso ovoide con gollete, asas de cinta, decoración impresa cardialoide. 11. Vasos semiesféricos, asas de puente con apéndices. 12. Vaso de boca cuadrada.

Procedencia:

1-4-6: Cueva de Nerja (Málaga). 2: Cueva del Plato (Castillo de Locubín, Jaén). 3: Cueva de Guadalijar (Jaén). 7: Cueva de la Chatarra (Castillo de Locubín, Jaén). 8-11: Cueva del Agua de Prado Negro (Iznallóz, Granada). 12: Cuevas de Alhama de Granada.

1, 4-6: según M. Pellicer y P. Acosta. 2, 3, 7-11: según M. S. Navarrete y J. Carrasco. 12: según M. PELLICER. 
de moda los grandes brazaletes de mármol, muy anchos con estrías grabadas paralelas o sin ellas, así como los brazaletes de pizarra o piedras negras en forma de aro o corona circular, cuyo origen, por su abundancia, se localizaría en la costa malagueña. El hallazgo de brazaletes de mármol sin estrías en el interior (Carigüela, Molaina), inconclusos, hace pensar que también se fabricaron «in situ». Los brazaletes de pectúnculo por su fragilidad se hallan fragmentados y reutilizados para colgantes. Son normales los anillos de hueso con o sin protuberancia y los tubitos de huesos largos cortados, así como las coronas circulares de hueso. Las cuentas y colgantes adquieren especial variedad, tanto en formas como en materias, como las placas de concha perforadas, las conchas perforadas de diferentes especies, como dentalium, conus, cardium, pectunculus, columbella, cerastoderma, cypraea, cerithium, todas ellas marinas, que penetran hacia el interior por comercio. Otros tipos son los dientes perforados y las cuentas de piedra (figura 5).

\section{Economía}

Pocas investigaciones de fauna se han realizado, si exceptuamos Nerja, donde los mamíferos del neolítico se estudiaron en dos fases. No obstante se observa cierta preponderancia de la fauna doméstica sobre la salvaje, estando aquella representada, en proporción decreciente, por bóvidos, cerdo y ovicápridos, como sucede igualmente en Los Castillejos de Montefrío. En las cuevas de la Carigüela, Nacimiento y del Toro, el ovicáprico prevalece frente al bóvido y cerdo. En general, la domesticación se impone a la caza. En la costa las especies marinas, tanto la ictiofauna como la malacofauna, forman una parte muy sustancial de la dieta alimenticia, sobresaliendo el consumo de «patella» sobre otras especies.

Respecto a la agricultura, solamente está constatado el cultivo del trigo en la cueva del Toro (estrato IV), estando todavía ausente en la cueva de Nerja. La Carigüela sigue problemática. Como dieta prosiguen también las bellotas y piñones. Por otra parte, la frecuencia de cerámicas, con negro de humo en su exterior y con restos quemados en su interior, constatan un cambio en la preparación de los alimentos.

\section{Ritos funerarios}

Como anteriormente, la cueva sirve tanto de habitat como de enterramiento, según los hallazgos de enterramientos individuales escogidos, con 

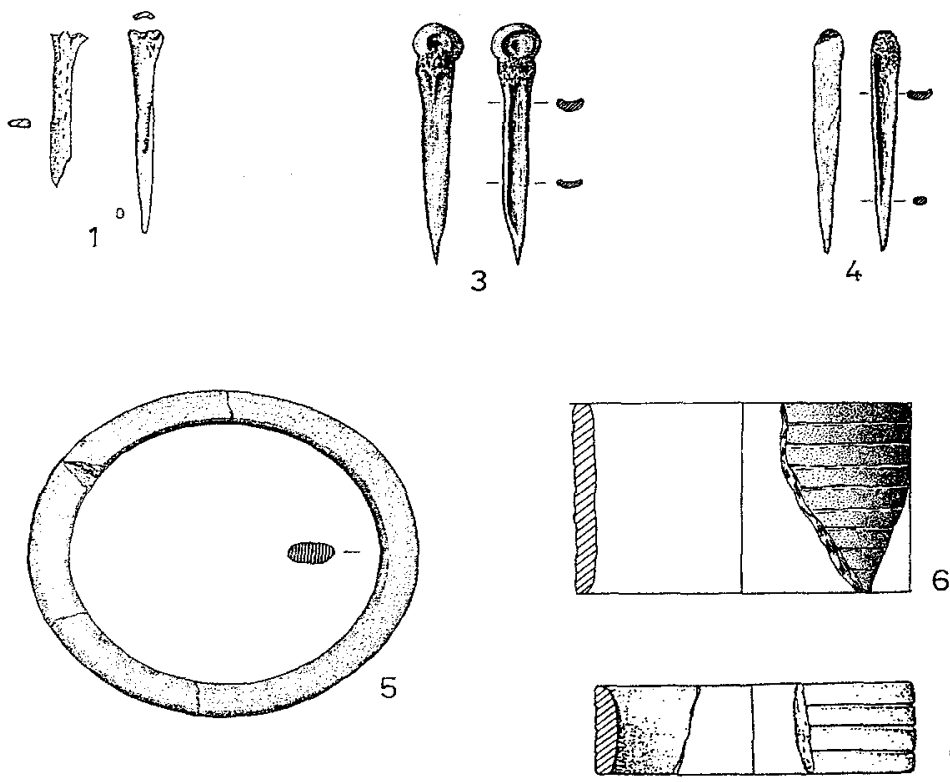

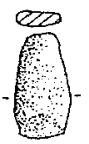

14

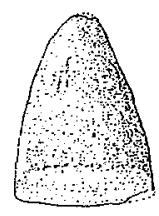

2

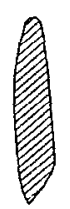

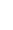

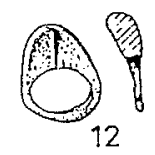

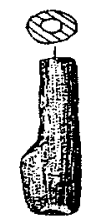

8

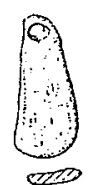

10

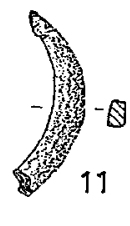

13

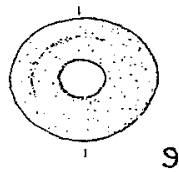

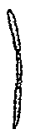

9

Fig. 5. Neolítico Medio.

1. Punzones de metapodios de ovicápridos. 2. Azuela de piedra pulimentada. 3. Punzón de metapodio de ovicáprido en media caña. 4. Id. 5. Brazalete de esquisto en corona circular. 6. Brazalete de mármol cilíndrico con estrías. 7. Id. 8. Cuenta-tubular de hueso. 9. Corona circular de hueso. 10. Diente perforado. 11. Colgante de pectúnculo. 12. Anillo de hueso con protuberancia. 13. Colgante de hueso. 14. Hachita de piedra pulimentada.

Procedencia:

1, 2, 7, 9-14: Cueva de Nerja (Málaga). 3-5: Cueva del Agua de Prado Negro (Iznalloz, Granada). 6: Cueva de los Molinos (Alhama de Granada). 8: Cueva CV-3 (Cogollos Vega, Granada).

1, 2, 7, 9-14: según M. Pellicer y P. Acosta. 3 y 4 : según M. S. Navarrete y J. Carrasco. 5,6 y 8: según $M$. S. Teruel. 
el cráneo manchado de ocre y sin ajuar aparente, de las cuevas de Nerja y del Agua de Alhama.

\section{Arte rupestre}

Sin duda, el arte rupestre esquemático, tan abundante en los macizos montañosos del norte de Andalucía oriental, discurre igualmente en el neolítico medio, según corroboran ciertos motivos decorativos de cerámicas, como los ramiformes y esteliformes de Nerja, Carigüela, Prado Negro, Carburero y la Mujer, o los antropomorfos de Salar y Prado Negro. Es posible que el arte llamado seminaturalista del círculo de Quesada, así como otros conjuntos de Sierra Morena, puedan colocarse en el neolítico medio.

\section{Habitat}

Según los yacimientos localizados, predominan todavía los habitats en cueva con frecuentes hogares de barro o piedras (Nacimiento). En el estrato inferior de Castillejos de Montefrío tenemos un ejemplo de habitat en abrigo rocoso con estructuras de piedra alineadas, restos de tapial con improntas de ramaje y estuco pintado de rojo. Prosiguen los yacimientos de superficie de la etapa anterior, surgiendo otros nuevos en toda la cuenca del alto Vélez, considerados como talleres de industria lítica.

\section{Yacimientos}

Aproximadamente en todo el territorio considerado se tienen localizados una treintena de yacimientos, de los que un tercio son ya de superficie. Se extienden por Almería (Cóbdar, Rioja), Jaén (Hornos de Segura, Castillo de Locubín, Otiñar, Huelma), Granada (Alhama, Alfacar, Montefrío, Iznalloz, Cogollos Vega, Motril, Loja, Baza) y Málaga occidental (Nerja y conjunto del río Vélez). De todos ellos han sido excavados o sondeados, con más o menos fortuna, la mitad. En la otra mitad solamente se ha practicado una somera recolección superficial de materiales sin contexto. Los principales yacimientos excavados son las cuevas de la Carigüela, Nerja, del Agua, del Capitán, de Ambrosio, del Toro y el abrigo de los Castillejos de Montefrío. Su adscripción al neolítico medio se constata por la presencia de cerámicas decoradas con motivos geométricos incisos. En ellos 
corresponden a esta etapa u horizonte los niveles 11-7 de la Carigüela, 3 del Capitán, VI B-A de Castillejos, IV del Toro y, respecto a la cueva de Nerja, corresponden a este horizonte los niveles 8 (NT-82), 3-2 (NM-79 NM-80 A), 9-8 (NM-80 B y 4-3 (NM-84 A y NM-84 B).

\section{Estadios}

Con los pocos estudios estratigráficos disponibles es difícil marcar estadios y, éstos, artificialmente, sin que se observen cambios o evoluciones aparentes dentro del neolítico medio. Solamente en la Carigüela, Nerja y Castillejos se han hecho intentos de obtener estadios, denominados A y B, según la división estratigráfica antes indicada. Al estadio o fase A del neolítico medio podría aplicársele una cronología de la segunda mitad del $V$ milenio y la fase B caería dentro de la primera mitad del IV milenio a. C. Seguimos opinando que el neolítico medio en sus fases A y B de Andalucía oriental, coetáneo al levantino, estaría desplazado en un par de siglos de retraso con relación a Andalucía occidental, aunque las pruebas permanecen débiles.

\section{Facies regionales}

Dado el deficiente estado de investigacióin, podría aventurarse una división de facies regionales en Andalucía oriental, análoga a la propuesta en el neolítico antiguo, con la inclusión de nuevos yacimientos.

\section{NEOLITICO FINAL}

Región considerada

Provincias de Almería, Jaén, Granada y parte oriental de Málaga.

\section{Nombre de la cultura}

La tercera etapa del neolítico, atendiendo a la evidencia arqueológica, a la sucesión estratigráfica y a la cronología radio-carbónica, se denomina neolítico final, reciente o tardío. Tratándose de un momento u horizonte cultural, en que comienzan a estar presentes ciertos elementos, que serán característicos del calcolítico, como las figuritas antropomorfas o idolillos 
(Carigüela), los platos carenados, las pesas de telar o el enterramiento colectivo o megalítico, puede también considerarse como fase de transición o neolítico de transición. La vieja terminología de cultura de Almería ha caído en desuso por defecto o restricción.

\section{Datación}

El neolítico final ha podido ser delimitado estratigráficamente en la Carigüela (niveles 6 - 3), en varios cortes de la cueva de Nerja, en el nivel I de la cueva del Capitán, en la fase $\|$ de los Castillejos de Montefrío y en el nivel III de la cueva del Toro. En Nerja se dispone de las fechas $3115 \pm$ 40 a. C. (calibrada $3910-3777$ a. C.) y $2860 \pm 220$ a. C., entre otras, y en la cueva del Toro III de $3500 \pm 120$ y $3370 \pm 230$ a. C. Otras fechas disponibles son $3450 \pm 80$ a. C. (calibrada: $4415-3955$ a. C.) en la cueva de los Murciélagos de Albuñol, y $3420 \pm 350$ a. C. (calibrada: $4575-3770$ a. C.) y $3705 \pm 115$ a. C. (calibrada: $3610-3350$ a. C.) en Terrera Ventura. Calculando, en función de fechas radiocarbónicas sin calibrar, el neolítico final oscilaría entre 3500 y 2800 a. C., pero utilizando fechas calibradas, podría alcanzar fechas un milenio más elevadas.

\section{Extensión geográfica}

La distribución geográfica sigue aproximadamente las pautas del neolítico medio, pero surgen "ex novo" una serie de emplazamientos de superficie en detrimento de las cuevas, repoblándose más intensamente la campiña gienenese, el altiplano y Genil granadino, la vertiente sur de la Axarquía y las cuencas bajas de los ríos almerienses Almanzora, Antas y Aguas, donde se consolida la cultura de Almería (figura 6).

\section{NEOLITICO FINAL}

\begin{tabular}{lccc}
\hline \multicolumn{1}{c}{ YACIMIENTOS } & LABORATORIOS & FECHAS B. P. & CALIBRACIÓN B. C. \\
\hline Cueva del Toro (Antequera, Málaga) (III) & & $5450 \pm 120$ & \\
Cueva del Toro (Antequera, Málaga) (III) & & $5320 \pm 230$ & \\
Cueva de los Murciélagos & CSIC - 246 & $5.400 \pm 80$ & $4415-3955$ \\
(Albuñol, Granada) & & $5370 \pm 350$ & $4575-3770$ \\
Terrera Ventura (Tabernas, Almería) & HAR - 155 & $4655 \pm 115$ & $3610-3350$ \\
Terrera Ventura (Tabernas, Almería) & GrN - ? & $5065 \pm 40$ & $3910-2775$ \\
Cueva de Nerja (Málaga) (Vest/1 B) & Gak - 8960 & $4810 \pm 210$ & \\
Cueva de Nerja (Málaga) (Vest1/B) & &
\end{tabular}




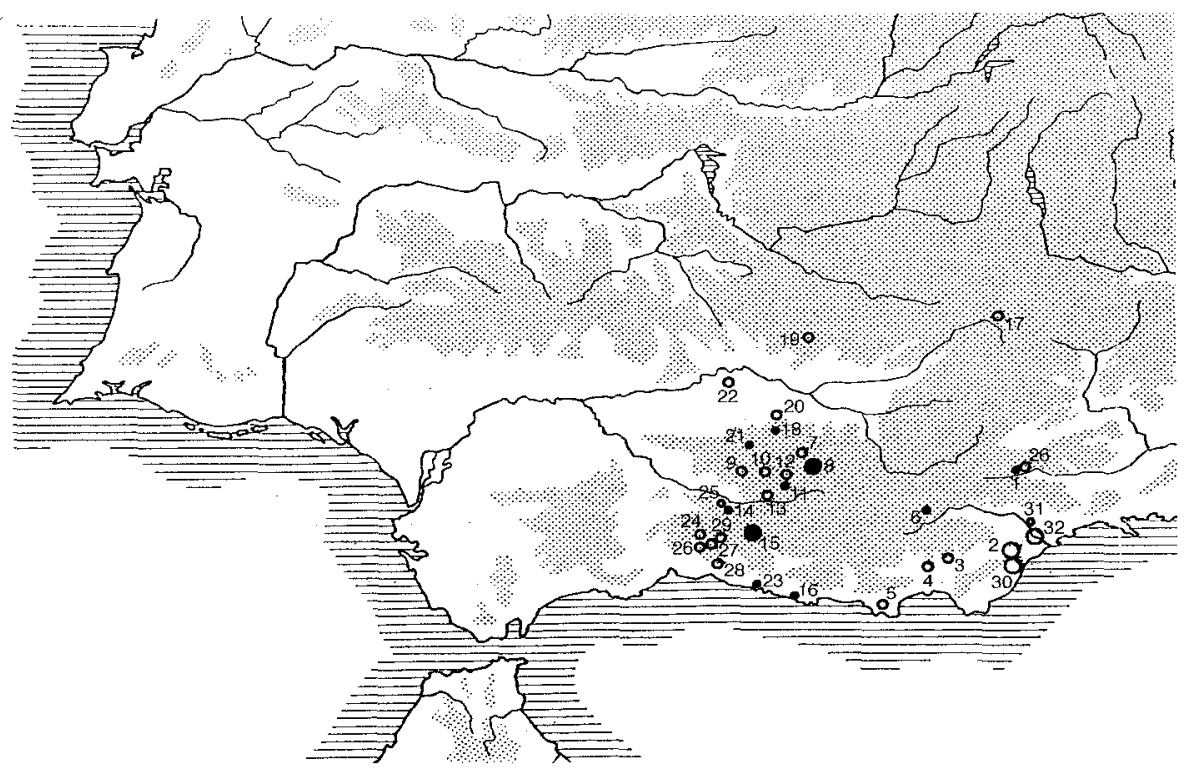

Fig. 6. Neolítico Final (Segunda mitad del $\mathrm{N}$ milenio - Principios del III milenio)

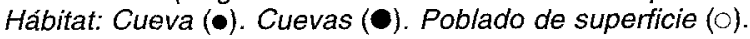

1. Cueva de Ambrosio (Vélez Blanco, Almería). 2. Poblados de Antas (Almería): Loma de Rutillas. Cañada del Jurado. 3. Terrera Ventura (Tabernas, Almería). 4. Cerro de la Chinchilla (Rioja, Almería). 5. Cíavieja (Dalías, Almeria). 6. Cueva de Caniles (Granada). 7. Cerro del Castel!ón (Campotéjar, Granada). 8. Cuevas de Pínar (Granada): Carigüela. Ventana. 9. Peña de los Gitanos (Montefrio, Granada). 10. Tajo del Minillo (Moclín. Granada). 11. Cueva de las Majolicas (Alfacar, Granada). 12. Llano de las Canteras (Alfacar. Granada). 13. La Molaina (Pinos Puente, Granada). 14. El Manzanil (Loja. Granada). 15. Cuevas de Alhama de Granada: Mujer. Agua. Los Molinos. 16. Cueva del Capitán (Salobreña. Granada). 17. Hornos de Segura (Jaén). 18. Cueva del Canjorro (Otiñar, Jaén). 19. El Ochavo (La Carolina, Jaén). 20. Huerto Berenguer (Jaén). 21. Cueva del Plato (Castillo de Locubín, Jaén). 22. Cerro Venate (Arjonilla, Jaén). 23. Cueva de Nerja (Málaga). 24. Conjunto de Tajo de Gomer (Ríogordo, Málaga). 25. Cueva del Coquino (Loja, Granada). 26. Peña de Hierro (Cútar, Málaga). 27. Benamargosa (Málaga). 28. Cerca Niebla (Vélez Málaga, Málaga). 29. Cortijo de la Herriza (La Viñuela, Málaga). 30. Poblados de Mojácar (Almería): Cuartillas. Mojácar la Vieja. Raja de Ortega. Loma del Acebuchal. 31. Huercal (Almería). 32. Poblados de Cuevas del Almanzora (Almería): Almizaraque. Tres Cabezos. Las Palas.

\section{Cerámica}

El cambio, tanto en formas como en la decoración de los vasos, es definitivo. Los vasos tienden a aumentar el volumen, perdiendo calidad las pastas y tratamientos. Las formas tienden a abrirse con la generalización de los bordes indicados. La decoración pierde entidad con predominio absoluto de superficies lisas. Persisten arcaísmos, como las formas semiesféricas, los cuencos y grandes vasos ovoides 
con asas de cinta, los cerrados con débiles carenas, los exvasados, surgiendo ya la fuente o plato. Más característicos son los vasos de perfil en $S \circ Z$ con el borde abruptamente indicado. La diversificación anterior de asas se restringe a los mamelones simples y de lengüeta. En cuanto a la decoración, persiste débilmente la almagra, los relieves de cordones y surcos, las incisiones de series de trazos, paralelas inclinadas, "chevrons", motivos en espiga, cuadrúpedos esquemáticos (Nerja), apareciendo la técnica pintada (Huerto Berenguer, Canjorro, Castillejos) (Figura 7).

\section{Industria lítica}

El sustrato anterior persiste con ciertas modificaciones porcentuales, debilitándose sensiblemente el raspador, buril y dorso. Las láminas y lascas predominan sobre las laminitas, destacándose las de retoque continuo, denticulados y, por supuestos, las huellas de uso. Prosiguen las láminas de borde abatido, muescas y fracturas. Se inician los grandes talleres al aire libre, como los de la alta cuenca del río Vélez, con cierta abundancia de geométricos, y poblados como el Garcel, donde la abundancia de geométricos trapezoidales y triangulares es notable. La industria lítica pulimentada aumenta en número, especialmente la azuela frente al hacha, la hachita y el alisador. Los molinos planos y naviformes, las moletas y machacadores, sin estar manchados de ocre, se han generalizado.

\section{Industria ósea}

Se debilita respecto al horizonte anterior, persistiendo formas análogas, como los punzones biselados de metápodos y los de media caña. Son frecuentes las espátulas, apareciendo la tipología que denominamos en abanico o de cabeza amplia sobre hueso plano, el tensador textil o separador de cuentas de collar, consistente en una laminita con perforaciones (Nerja, Toro), persistiendo el anillo (Capitán).

\section{Adornos}

Se observa cierta disminución de los adornos personales. Continúan, esporádicamente y arcaizantes, los brazaletes de mármol y 

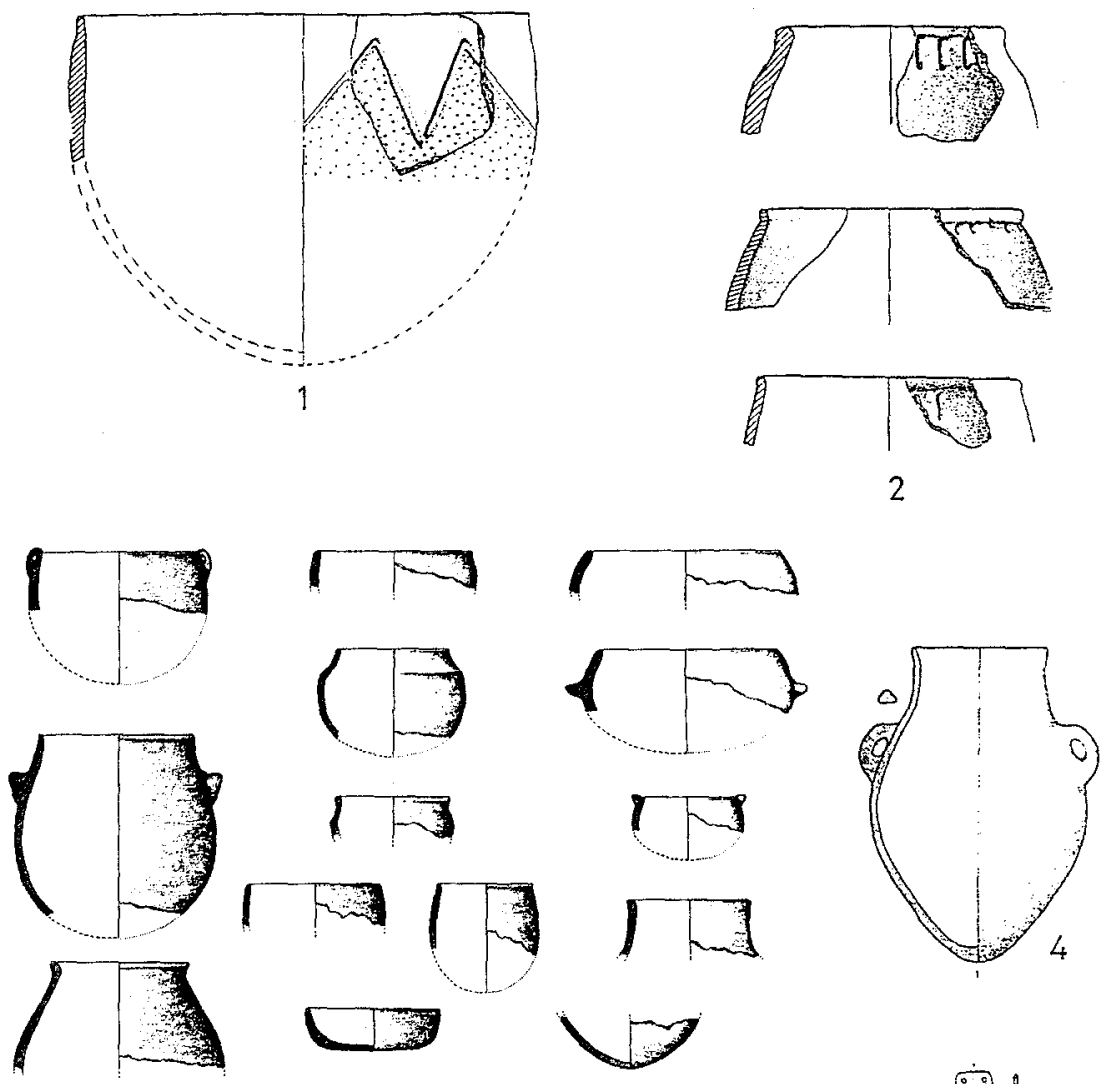

3

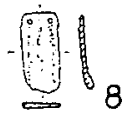

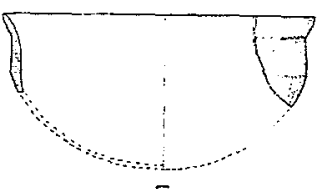

5

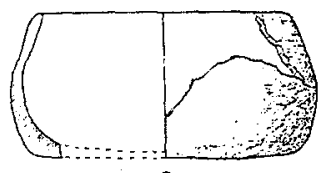

6

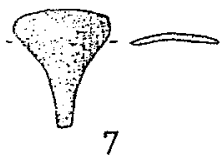

7

Fig. 7. Neolitico Final.

1. Vaso semiesférico, borde biselado, decoración incisa y puntillada. 2. Tres vasos ovoides, con borde indicado, decoración íncisa de trazos. 3. Formas de vasos. 4. Vaso ovide con gollete y asas de cinta. 5. Vaso semiesférico, borde exvasado. 6 . Vaso de tendencia troncocónica. 7. Espátula-punzón de hueso con cabeza en abanico). 8. Colgante-plaquita de hueso. Procedencia:

1, 2, 4-8: Cueva de Nerja (Málaga). 3: Cueva del Agua de Prado Negro (Iznalloz, Granada). 1, 2, 4-8: según M. Pellicer y P. Acosta. 3: según M. S. Navarrete y J. Capel. 
los de pizarra, generalizándose los brazaletes de pectúnculo, que serán característicos del calcolítico. Siguen frecuentes los colgantes de diferentes piedras perforadas, los tubitos de hueso y los dientes perforados.

\section{Economía}

La fauna doméstica se equipara o prevalece frente a la salvaje, que en las sierras del norte conserva su vigencia. En Nerja el $65 \%$ es doméstica, con unas proporciones de $31 \%$ de ovicápridos, $15 \%$ de bóvidos y $15 \%$ de cerdo. En los Castillejos de Montedrío la fauna doméstica ocupa el $68 \%$, con proporciones de $29 \%$ de ovicáprido, $31 \%$ de bóvido y $9 \%$ de cerdo. En la cueva del Toro la cabra y el cerdo predominan sobre el buey y la oveja. En la costa tienen especial protagonismo las especies marinas, tanto de peces como malacofauna, ocupando la patella el $58 \%$, thaïs el $20 \%$, monodonta el $10 \%$ y el mytilus el $8 \%$.

La agricultura cerealística se ha generalizado ya por toda la geografía. El silo hallado en Nerja entregó trigo (espelta, exaploide y tetraploide), cebada (hordeum vulgare, polysticum, var. nudum), piñones, bellotas y olivas. En el estrato III de la cueva del Toro se localizó trigo común y cebada desnuda, bellotas, habas y lentejas, en la Carigüela se documentó el tricum dicoccum, en los Murciélagos de Albuñol triticum aestivum, piñones y bellotas y en el Garcel fueron identificadas olivas y vid, al parecer, silvestres.

Los análisis petrográficos de instrumentos de piedra de Nerja constatan unas redes comerciales con la Meseta, Serranía de Ronda y Sierra Nevada.

\section{Ritos funerarios}

En Nerja los enterramientos individuales, con el cadáver encogido, continúan practicándose en el habitat, hecho confirmado en Castillejos de Montefrío, donde se utiliza la fosa en su fase II. Es posible que algunos enterramientos múltiples con estructuras circulares («Rundgräber») del sureste de Almería, correspondientes a la fase I de los Leisner, se iniciasen en este horizonte. 


\section{Arte rupestre}

La localización, en el neolítico final de Nerja, de cerámicas con representación incisa de cabras montesas, análogas a las de algunos abrigos pintados de Despeñaperros y Sierra de Segura, confirman este horizonte, independientemente de su pervivencia calcolítica. Los esteliformes y ramiformes, constatados en cerámicas del neolítico medio y calcolítico, son prueba evidente de su vigencia, incluso en el neolítico final, momento al que podrían adscribirse estos motivos representados en los abrigos de las sierras de Filabres, Estancias, Sagra, Segura y Despeñaperros.

\section{Habitat}

Los yacimientos al aire libre se multiplican en zonas llanas y terrazas fluviales en detrimento del habitat en cueva. Surgen tres círculos o facies, como preludio del horizonte calcolítico, en la cuenca del río Vélez, en la gran extensión entre el Genil y el Guadalquivir, ocupándose el altiplano granadino y la campiña giennense, y en las bajas de los ríos Almanzora, Antas y Aguas de Almería. Si en el neolítico y medio la proporción de yacimientos en cueva con respecto a los de superficie es de 3 a 1 , con el neolítico final esta proporción se invierte. Pocas nociones tenemos acerca de las dimensiones, formas y estructuras internas de estos establecimientos de superficie, aunque se ha constatado la existencia de cabañas circulares, trincheras, fosos y fondos de cabaña.

\section{Yacimientos}

En menor intensidad prosigue la habitación en cueva, según los testimonios de las cuevas granadinas de la Carigüela (Piñar), Las Majolicas (Alfacar) y Capitán (Salobreña), de las cuevas gienenses del Plato (Castillo de Locubín) y del Canjorro (Jaén), de las malagueñas de Nerja y del Toro (Antequera) y de las almeriense de Ambrosio (Vélez Blanco). Los establecimientos de superficie se generalizan en las zonas Ilanas y depresiones, siendo los yacimientos más significativos en Jaén, Huerto Berenguer (Jaén), el Ochavo (La Carolina), Cerro Venate (Arjonilla) y Hornos de Segura. En Granada el Llano de las Canteras (Alfacar), Los Castillejos (Montefrío), Cerro del Castellón (Campotéjar), La Molaina 
(Pinos Puente), los Molinos (Alhama), Tajo de Molinillo (Moclín) y el Manzanil (Loja). En Málaga Tajo de Gomer (Ríogordo), Peña de Hierro (Vélez Málaga) y Río Benamargosa. En Almería Cíavieja (El EjidoDalías), Terrera Ventura (Tabernas), Cerro de la Chinchilla (Rioja) y los conjuntos de los ríos Antas (Garcel, Loma de Rutillas, Cañada del Jurado), Aguas (Cuartillas, Mojacar la Vieja, Raja de Ortega, Loma del Acebuchal) y del Almanzora (Tres Cabezos, Las Palas y Almizaraque), que inauguran la cultura de Almería.

\section{Estadios}

En el estado actual de las investigaciones solamente han podido distinguirse fases dentro del neolítico final en las cuevas de Nerja y de la Cirigüela. En la cueva de Nerja corresponden a la fase o estadio A los niveles 7 (NT-82), 2 (NM-79 y NM-80 A), 7 (NM-80 B) y 2 (NM-84 B). En la fase $B$, más reciente, se incluirían los niveles 6 (NT-82), 1 (NM-79 y NM-80 A), 6 (NM-80 B) y $1(\mathrm{NM}-84 \mathrm{~B})$. En la cueva de la Carigüela, según la última revisión, ciertos niveles anteriormente considerados calcolíticos o del bronce 1 , es necesario adscribirlos al neolítico final A los niveles 6 y 5 , y al neolítico final $\mathrm{B}$, los niveles 4 y 3 . Cronológicamente, al neolítico final A podría asignársele una fecha de la segunda mitad del IV milenio y al neolítico final $\mathrm{B}$, los dos primeros siglos del III milenio, con prolongaciones en zonas retardatarias.

\section{Facies regionales}

Las facies regionales del neolítico antiguo y medio se ven aumentadas con la proliferación de yacimientos de superficie en las campiñas gienenses, altiplanicies granadinas, cuenca del Genil, Axarquía y sureste de Almería.

\section{CALCOLÍTICO}

Región considerada

Provincias de Almería, Jaén, Granada y parte oriental de Málaga. 
Nombre de la cultura

La primera fase del calcolítico ha recibido unos apelativos más o menos afortunados, creadores de cierta confusión. Correcto ha sido el término eneolítico con que se designa a la edad del cobre, todavía en uso. El término neoeneolítico, utilizado hasta los años cincuenta, dado su significado genérico e indefinido, perdió vigencia, adoptándose en el congreso de Almería de 1949 la nomenclatura inglesa de bronce 1, para distinguirlo del bronce II, bronce pleno o cultura del Argar. También se denominaba cultura de Los Millares I, dada la importancia paradigmática de este yacimiento. Hoy día el término más generalizado es el de calcolítico precampaniforme.

\section{Dotación}

Del calcolítico disponemos ya de numerosas fechas absolutas. La fase II de Terrera Ventura proporcionó seis fechas comprendidas, sin calibrar, entre 2.450 y 2.080 a. C. y, calibradas, entre 3.360 y 2.520 a. C. En Almizaraque la fase I ha entregado las fechas, no calibradas, entre 2.200 y 2.000 a. C. y las calibradas oscilan entre 2.915-2.635 y 2.420 2.290 a. C. De la muralla exterior de Los Millares poseemos las fechas, sin calibrar, de $2.345 \pm 85$ a. C. (calibrada: $3.155-2.870$ a. C.) y de su necrópolis la de $2.430 \pm 120$ a. C. (calibrada: 3.355-2.905 a. C.). De la necrópolis del Barranquete las fechas obtenidas son, sin calibrar, 2.350 \pm 130 y $2.330 \pm 130$, que, calibradas, corresponden respectivamente a $3.170-2.790$ a. C. y $3.165-2.780$ a. C. Del poblado del Tarajal, al que corresponde la necrópolis del Barranquete, se han obtenido doce fechas que, sin calibrar, oscilan entre 2.280 y 2.060 y, calibradas, entre 2.970 y 2.525 a. C. En Granada el poblado de las Angosturas de Gor se fecha, sin calibrar, en $2.260 \pm 140$ (calibrada: 3.040 - 2.640 a. C.) y $2.200 \pm$ 170 (calibrada: 2.965-2.545 a. C.). El poblado de el Malagón de Cúllar Baza se ha fechado, sin calibrar, en $2.565 \pm 215$ a. C. y $2.115 \pm 150$ a. C., que, calibrada la primera fecha, corresponde a $2.895-2.520$ a. C. Ante tal disparidad de fechas, según se calibre o no, y el amplio espectro cronológico de casi un milenio para sus inicios, $y$, por otra parte, atendiendo a su momento final con la aparición del vaso campaniforme a fines del III milenio, el calcolítico precampaniforme en Andalucía oriental, según fechas sin calibrar, parece discurrir en la segunda mitad del III milenio a. C. 
CALCOLITICO

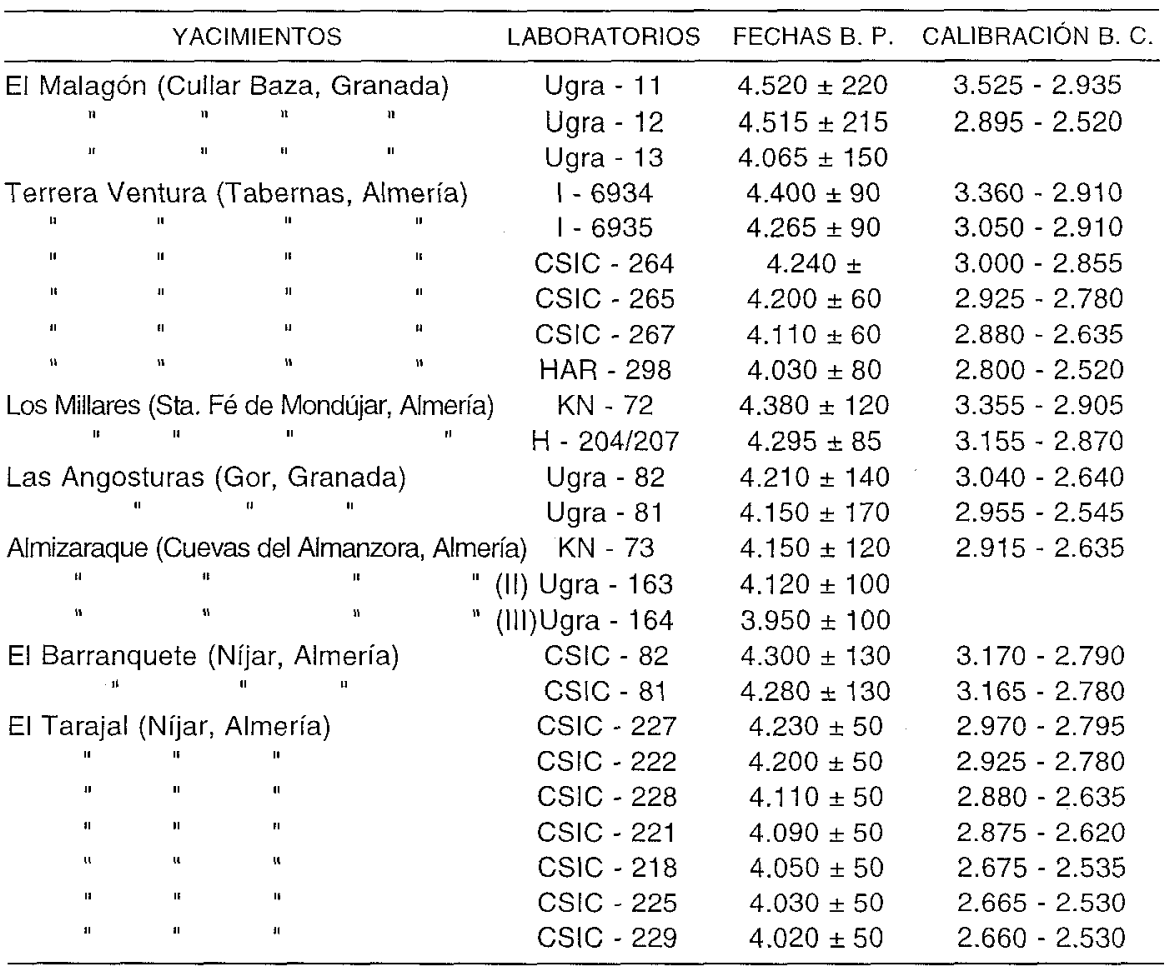

\section{Extensión geográfica}

Con el calcolítico se produce una de las mayores eclosiones demográficas de la prehistoria, multiplicándose la población en establecimientos de gran escala que surgen «ex novo» en los grandes valles y en los altiplanos, prosiguiendo, en ocasiones, la vida en los núcleos anteriores del neolítico final. En Almería tiene lugar la consolidación de la cultura de Almería, con centros nucleares como Los Millares, prosiguiendo precariamente la habitación en cuevas, como la de Ambrosio. En Granada, tanto en la depresión del Genil como en el altiplano, los establecimientos calcolíticos emergen en abundancia, como El Malagón, prosiguiendo habitados Los Castillejos de Montefrío, el Llano de las Canteras de Alfacar, El Manzanil de Loja, etc. y algunas cuevas como La Carigüela. Jaén, frente a la parquedad demográfica anterior, se desvela con inusitada fuerza en densidad de yacimientos, detectados en la campiña gracias a las intensas prospecciones, establecida una jerarquiza- 
ción política para estudiar la emergencia del estado. En Málaga oriental las cuevas del neolítico prosiguen habitadas, como la de Nerja, aumentando los yacimientos de superficie en la cuenca del río Vélez, en la costa (Morro de Mezquitilla, San Telmo) y en la Hoya de Antequera (figura 8).

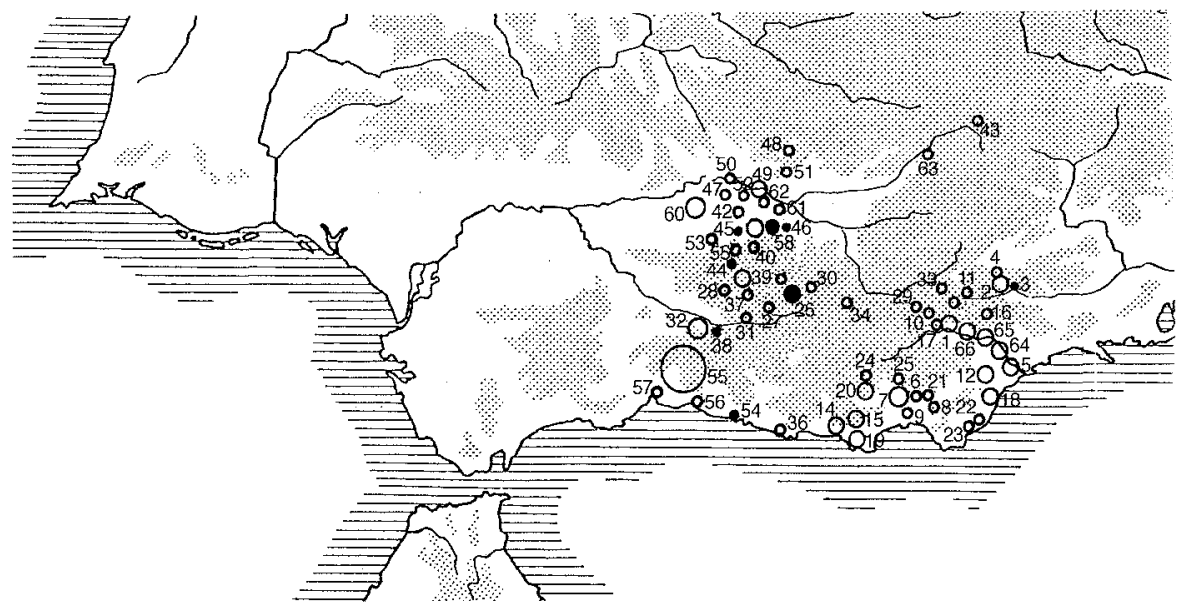

Fig. 8. Calcolítico (Principios del II milenio - Fines del II milenio)

Hábitat: Cueva ( $\bullet$. Conjunto de cuevas $(\bullet)$. Poblado de superficie $(0)$. Conjunto de poblados de superficie (O).

1. Conjunto de Purchena (Almería). 2. Conjunto de poblados de Vélez Rubio (Almería): Alquería. Cerro Redondo. El Pico. 3. Cueva de Ambrosio (Vélez Blanco, Almería). 4 Cerros de las Canteras (Vélez Blanco, Almería). 5. Poblados de Cuevas de Almanzora (Almería). Almizaraque. Tres Cabezos. Zájara. 6. Terrena Ventura (Tabernas, Almeria). 7. Poblados de GádoriSanta Fé de Mondújar (Almería): Los Millares. Loma de Huechar. El Mojón. Loma de Galera. Fortines de Los Millares. 8. El Tarajál (Nijar, Almería). 9. Cerro de la Chinchilla (Rioja, Almería). 10. El Hijate (Almería). 11. Chirivel (Almería). 12. Poblados de Antas (Almería): El Garcel. Gerundia. 13. Cerro del Picacho (Oria, Almería). 14. Poblados de Adra (Almería): Guainos Altos. Cerro de la Alquería. 15. Poblados de Berja (Almería): Rambia del Cid. Pago de las Chichas, Tajo de los Gavilanes. Beneji. 16. Sierra del Madroño (Taberno, Almería). 17. Serón (Almería). 18. Poblados de Mojácar (Almería): Loma del Campo. Macenas. La Viña. 19. Poblados de Dalías (Almeria): Cíavieja. Cellín. Cerrillo de los Atajuelos. 20. Canjáyar (Almería): Castillo de Veires.Cortijo de Tices. 21. Inox (Turrillas, Almería). 22. La Isleta del Moro (Almería). 23. Los Escullos (Almería). 24. Abla (Almería). 25. Peñón de las Juntas (Gergal, Almería). 26. Cuevas de Píñar (Granada): Carigüela, Ventana. 27. Llano de las Canteras y Majolicas (Alfacar, Granada). 28. Peña de los Gitanos (Montefrio, Granada). 29. El Malagón (Cúllar Baza, Granada). 30. Cerro de los Castellones (Laborcillas, Granada). 31. Cerro de los Infantes (Pinos Puente, Granada). 32. Loja (Granada): El Manzanil. Cortijo de la Caridad. 33. Cerro de la Virgen (Orce, Granada). 34. Las Angosturas (Gor, Granada). 35. Cerro del Castellón (Campotéjar, Granada). 36. El Hacho (Salobreña, Granada). 37. Cerro de Mingo Andrés (Moclín. Granada). 38. Cueva del Coquino (Loja. Granada). 39. Alcalá la Real (Jaén): Cerro de San Marcos. La Mesa. El Castillo. Cerro de San José. 40. Cerro Veleta (Otiñar. Jaén). 41. Jaén: Jabalcuz. Puente Tabla. 42. Torre Benzalá (Escañuela/Nillardonpardo. Jaén). 43. Hornos de Segura (Jaén). 44. Cueva de la Cabeza Baja (Castillo de Locubín, Jaén). 45. Cueva del Miguelico (Torre del Campo, Jaén). 46. Cueva de las Zorreras (Albanchez de Úbeda, Jaén). 47. Cerro Venate (Arjonilla, Jaén). 48. El Ochavo (La Carolina, Jaén). 49. Cazalilla (Jaén): La Atalaya. Cerro de la Coronilla 1. 50. Las Tiesas (Espeluy, Jaén). 51. Los Patos (Linares, Jaén). 52. Los Pozos (Higuera de Arjona, Jaén). 53. Cortijo de la Alcaparra (Santiago de Calatrava, Jaén). 54. Cueva de Nerja (Málaga). 55. Conjunto de poblados - taileres del río Vélez (Málaga): Peña de Hierro (Cútar), Tajo de Gomer (Ríogordo), Poblados de Periana (Cerro de Capellanía, Las Mezquitillas, Cerro Alcolea, Marchamonas), Los Colmenares, Cerca Niebla (Vélez Málaga), Herrera (La Viñuela), Cortijo de la Cueva (Alfarnatejo). 56. Morro de Mezquitilla (Algarrobo, Málaga). 57. San Telmo (Málaga). 58. Cueva del Canjorro I y III (Jaén). Cueva del Caño Quebrado (Jáen). 59. Nava (Martos, Jaén). 60. Porcuna (Jaén): Alcores. Albalate. Cerro del Berral. Cortijo de los Pilines. Vista Alegre. 61. Villagordo (Jaén). 62. Atalayuelas (Mengíbar, Jaén). 63. Puente del Río de la Vega (Santo Tomé, Jaén). 64. Conjunto de Zurjena (Almería). 65. Conjunto de Albox (Almería). 66. Conjunto de Cantoria (Almería). 


\section{Cerámica}

La característica constante es la abundancia de grandes vasos, la tosquedad, la casi ausencia decorativa y la tendencia generalizada a las formas abiertas con bordes exvasados, como los grandes platos o fuentes. Entre las formas abiertas destacan los cuencos semiesféricos, los cilíndri$\cos$, bordes indicados, perfiles en $S$, panzas carenadas, bases planas $y$, entre las formas cerradas, menos comunes, los vasos con carena indicada, hombros entrantes troncocónicos y ovoides. Los elementos de prehensión han desaparecido sensiblemente, excepto los mamelones y lengüetas, perforados o no, persistiendo débilmente el asa de cinta y los grandes mangos de cazo. Los platos se inician con las paredes ligeramente convexas para dar paso a los carenados, que, de origen occidental, llegan hasta Jaén, conviviendo en momento avanzado con los de borde gruesa saliente o almendrado, enrarecidos conforme avanzan hacía la parte más oriental.

Las decoraciones, raras, admiten las técnicas de la incisión, el trazo, el puntillado, la pintura, conservándose débilmente la técnica plástica de los cordones y las pastillas repujadas (Castillejos VA), al parecer de origen ultrapirenáico. Los motivos decorativos toman fuerza en las cerámicas simbólicas de Los Milares y Malagón con geometrismos, zigzags, esteliformes (Fonelas, Millares), zoomorfos, ramiformes, con técnica incisa (Toro) y pintada (Castillejos, Millares, Campos, Terrera Ventura, Tarajal), que aumentará en el campaniforme (figura 9).

\section{Industria lítica}

La industria lítica tallada se caracteriza por la presencia de grandes piezas o macroindustria en lo referente a láminas de retoque continuo. Son frecuentes las láminas con cresta, denticuladas, núcleos, buriles, raspadores y perforadores. Aparecen los foliáceos en sus especies de macroindustria, representada por puñales y alabardas, y microindustria de puntas de flecha, resurgiendo intensamente los microlitos geométricos. Las puntas de flecha características son las de aletas y pedúnculo, las de base recta y las lanceoladas, siendo raras las de base cóncava, de influencia occidental. Los pulimentados siguen la pauta del neolítico final.

\section{Industria ósea}

La industria del hueso aumenta en volumen y variedad tipolótica, siendo frecuentes los punzones de metápodos, los de punta en bisel y los de 

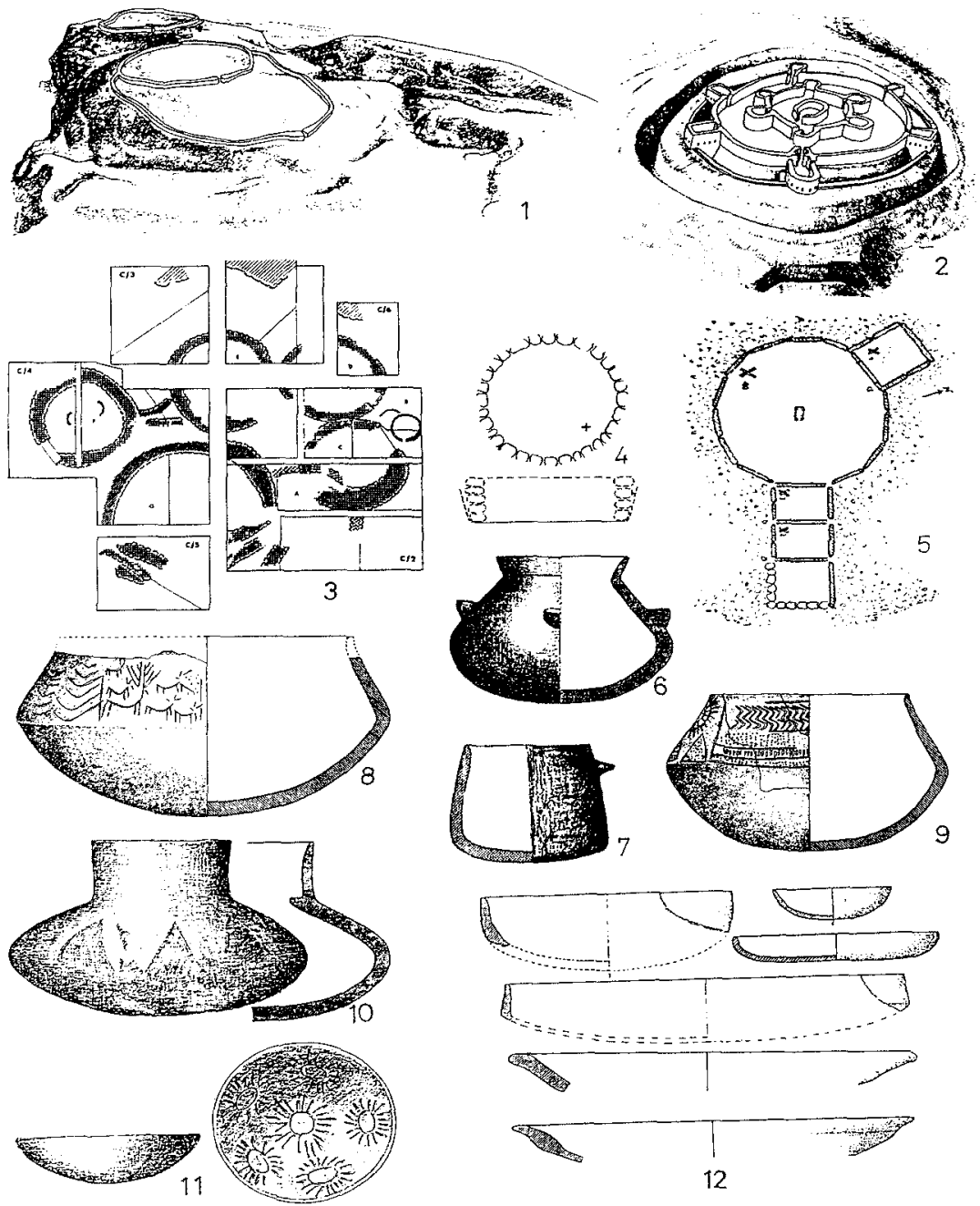

Fig. 9. Calcolítico.

1. Recintos fortificados de Los Millares. 2. Fortín. 3. Planta de poblado. 4. Rundgrab o cámara circular de enterramiento. 5. Tholos. 6. Vaso bitroncocónico. 7. Vaso troncocónico. 8. Vaso carenado, decoración incisa de cérvidos. 9 . Vaso carenado, decoración incisa de oculados. 10. Vaso lenticular con gollete, pintado. 11. Cuenco semiesférico, decoración incisa de esteliformes. 12. Platos con formas de casquete esférico, carenadas y borde grueso.

Procedencia:

1, 2, 5, 8: Los Millares (Santa Fe de Mondújar, Almería). 3: El Malagón (Cullar Baza, Granada). 4: Loma de la Atalaya (Purchena, Almería). 6: Llano del Jautón (Purchena, Almería). 7: Llano de la Lámpara (Purchena, Almería). 12: Cueva de Nerja (Málaga).

1-3: según A. ArRibas. 4-11: según G. y V. Leisner. 12; según M. Pellicer y $P$. Acosta. 
media caña y planos, las espátulas, agujas, varillas, leznas, alisadores, alfileres de cabeza cilíndrica estriada y de cabeza ancha, peines (Castillejos, Canjorro III, Millares), botones de hueso o marfil semiesféricos de tipo Dufort, cónicos o piramidales con perforación en $\mathrm{V}$ (Cerro de la Virgen, Castillejos).

\section{Metalurgia}

Aunque el nombre de calcolítico se refiere a la edad del cobre, este elemento es extraño en los inicios del horizonte. En el calcolítico el metal no es significativo ni afecta apenas a la economía. La metalurgía del calcolítico se detecta por las escorias (Castillejos) y crisoles (Venate, Malagón, Almizaraque, Cerro de las Canteras), exponente de esta actividad y por la presencia de azurita y malaquita (Malagón, Almizaraque). Los primeros artefactos son pequeños punzones (Almizaraque San Marcos, Castillejos, Toro II, Malagón), seguidos por cuchillos curvos (Malagón, Castillejos), escoplos, hachas planas trapezoidales (Almizaraque, Marroquíes Altos), sierras (Malagón, Cerro Venate) y cinceles (Almizaraque). Probablemente la técnica del oro batido se iniciaría en este período, según la diadema de Albuñol (figura 10).

\section{Adornos}

Las piezas de ornamento personal y de tipo ritual adquieren especial auge por la diversidad de materias primas y tipología. Las conchas perforadas siguen sirviendo de colgantes (Toro) y el pectúnculo se convierte definitivamente en el típico brazalete ("Rundgräber» de Almería, Malagón). Las cuentas de piedra perforadas de la más variada naturaleza forman parte del ajuar de los enterramientos colectivos. Se introducen, como producto del comercio a gran escala, las cuentas de huevo de avestruz, de las que se hallaron cerca del millar en un «tholos» de Los Millares, así como el marfil (ambas materias de origen norteafricano) utilizado para la producción de botones con perforación en $V$ y objetos rituales, como los ídolos antropomorfos naturalistas (Cerro de la Virgen, Marroquies Altos, Torre del Campo) y las cuentas de ámbar, de origen atlántico, frecuentes en Los Millares. Pueden incluirse en los adornos las agujas de hueso de cabeza estriada o segmentada, colgantes segmentados, las plaquitas de hueso con varias perforaciones o separadores de cuentas de collar y las sandalias de mármol (Almizaraque) (figura 11). 

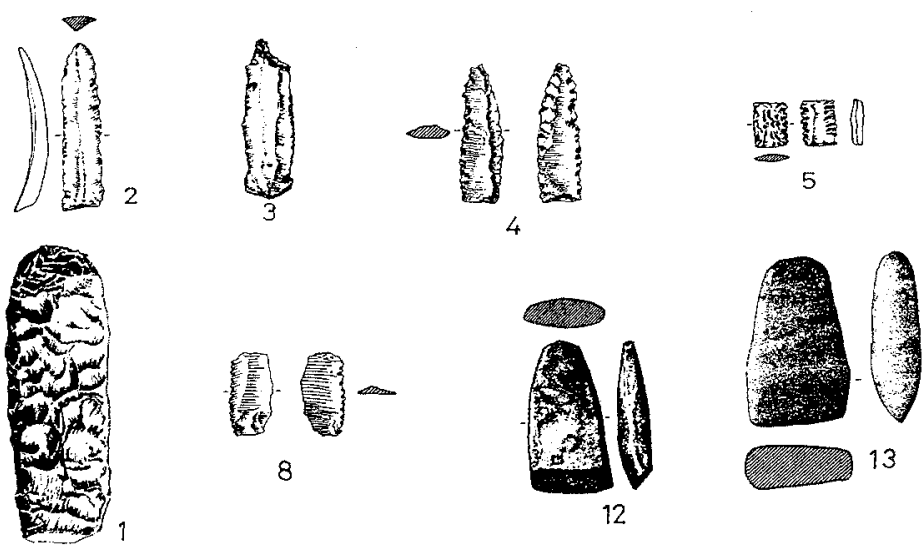

12
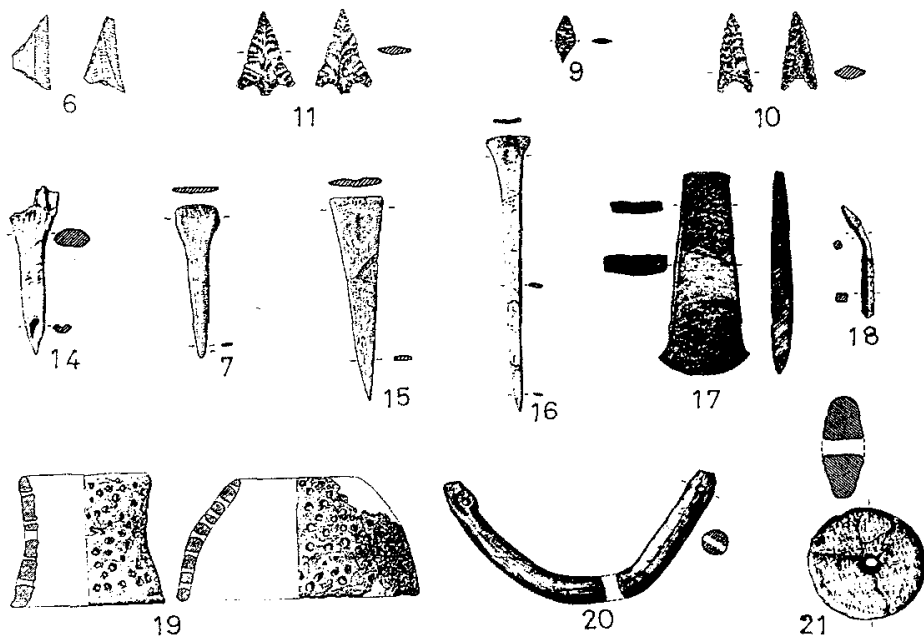

Fig. 10. Calcolítico.

1. Lámina de silex con retoque cubriente. 2. Lámina de silex retocada. 3. Lámina-buril de silex retocada. 4. Lámina de silex denticulada. 5. Diente de hoz. 6 . Microlíticos geométricos, trapezoidal y triangular. 7. Punzón-espátula de hueso con amplia cabeza. 8. Lámina detada. 9. Punta de flecha de silex romboidal. 10. Punta de flecha de silex de base cóncava. 11. Punta de flecha de silex de aletas y pedúnculo. 12. Azuela de piedra pulimentada. 13. Hacha de piedra pulimentada. 14. Punzón de matapodio de ovicáprido. 15. Punzón-espátula de hueso. 16. Punzón plano de hueso. 17. Hacha de cobre, trapezoidal, borde abierto. 18. Punzón de cobre, sección cuadrada. 19. Vasos con perforaciones, queseras. 20. Pesa de telar en creciente. 21. Fusayola de cerámica.

\section{Procedencia:}

$1-3,5,12,14,16,18,20$ y 21: Los Castillejos (Montefrío, Granada). 4, 7, 8, 10, 11, 13, 15 y 19: El Malagón (Cullar Baza, Granada). 6: Loma de la Atalaya (Purchena, Almería). 9 y 17: Loma de la Atalaya (Purchena, Almería). 9 y 17: Almizaraque (Cuevas del Almanzora, Almería). 1-5, 7, 8, 10-16, 18-21: según A. ARRIBAs. 6: según G. y V. LeISNer. 9 y 17: según G. DeLibes. 

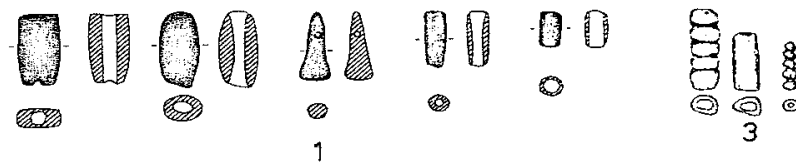

8

5

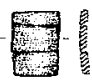

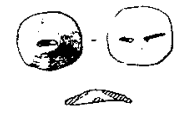

7
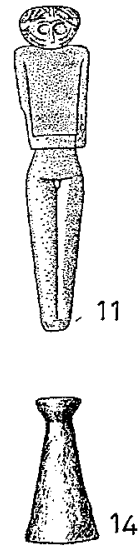
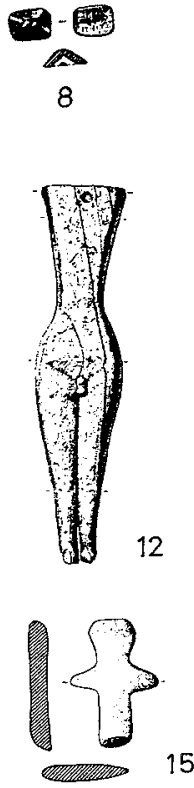<smiles>C=CC=CC=C</smiles>

口2000

5

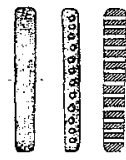

6

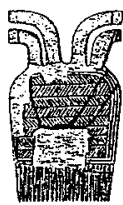

9
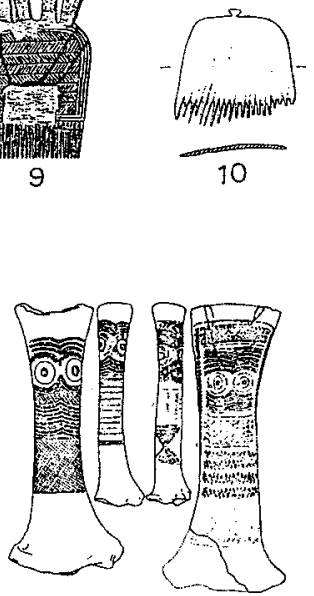

13

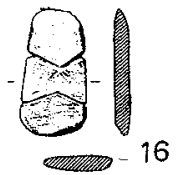

Fig. 11. Calcolítico.

1. Cuentas cilíndricas de collar de hueso. ?. Cuentas discoidales-cilíndricas de collar de piedra. 3. Cuentas segmentadas de hueso. 4. Dentalium. 5. Plaquita de hueso grabada. 6. Separador de cuentas de collar, de hueso. 7. Botón cónico con perforación en $V$, de marfil. 8. Botón piramidal con perforación en $\mathrm{V}$. de marfil. 9. Peine de marfil. 10. Peine de hueso. 11. Ídolo antropomorfo de marfil. 12. Id. 13. Ídolos grabados y pintados sobre huesos largos. 14. Ídolo-tolva de mármol. 15. Ídolo cruciforme de mármol. 16. Idoliforme de mármol.

\section{Procedencia:}

1, 2, 4-6: Covacha de la Presa (Loja, Granada). 3: Llano del Jautón (Purchena, Almería). 7 , 8, 10, 15, 16: Los Castillejos (Montefrío, Granada). 9 y 14: Los Millares (Santa Fe de Mondújar, Almería). 11: Torre del Campo (Jaén). 12: El Malagón (Cullar Beza, Granada). 13: Almizaraque (Cuevas del Almanzora, Almería).

1, 2, 4-6: según J. CarRasco. 3, 9, 14: según G. y V. LeISNer. 7, 8, 10, 15 y 16: según M. TARRAdell. 11 y 12: según A. ARRibas. 13: según H. y L. Siret. 


\section{Economía}

La climatología del período atlántico en su apogeo, más templado y húmedo, del ıv y III milenio a. C., contribuyó, sin duda, a la emergencia de la cultura del calcolítico, incidiendo directamente en la economía con el cambio y evolución de la flora y la generalización de la agricultura cerealística del trigo (Almizaraque, Malagón, Lugarico Viejo, Nerja, Tabernas, Montefrío), cebada (Almizaraque, Nerja, Laborcillas) y centeno (Garcel), de las leguminosas como lentejas (Campos) y habas (Almizaraque, Garcel) y del lino (Almizaraque), utilizándose para su recolección los abundantes dientes de hoz líticos. Se ha defendido para este momento la práctica del regadío, según se ha intentado demostrar en el Cerro de la Virgen de Orce. Existen dudas sobre el cultivo de la vid y el olivo. La frecuencia de grandes platos y recipientes abiertos sugiere un cambio en la dieta alimenticia a base de polentas. Las grandes extensiones cultivadas con cereales y gramíneas y explotadas sistemáticamente con policultivo y sistemas de rotación acopiarían excedentes, conservados en los inumerables silos abiertos en los poblados. surgiendo una sociedad clasista, según pretensión del materialismo histórico.

Respecto a la fauna doméstica hay predominio de ovicápridos, en Nerja el $32 \%$, en Terrera Ventura el $30 \%$, en el Cerro de los Castellones el $60 \%$, en Castillejos $11 / 14 \%$. El cerdo mantiene una proporción del $23 \%$ en Neria, 20\% en Castillejos, $15 \%$ en Terrera Ventura. El bóvido presenta el $10 \%$ en Nerja, $22 \%$ en Castillejos, $28 \%$ en Terrera Ventura y $15 \%$ en Cerro de los Catellones. Otra especie en menor proporción es el caballo, quizás utilizado como elemento y medio de transporte y trabajo, además de alimento (Castillejos, Terrera Ventura, Cerro de la Virgen). La fauna salvaje está constituída por jabalí, ciervo, corzo, conejo, liebre, uro, perro, cabra montés, asno, lince, gato montés, diferentes especies de aves (perdiz, ansar, paloma) y peces en la costa (Nerja, Capitán, Almizaraque) (en proporciones inferiores). La malacofauna de Nerja presenta unas proporciones de $37 \%$ patella, $30 \%$ monodonta, $18 \%$ thaïs, $11 \%$ mytilus y $2 \%$ caracol terrestre.

Con el calcolítico se generaliza la industria textil de lana y lino, según las pesas de telar con forma de placas o cilíndros curvos cerámicos con extremos perforados, y fusayolas. Los vasos cubiertos de perforaciones o coladores parecen documentar la industria del queso. Por ciertas materias de origen africano (marfil, huevos de avestruz), atlántico (ámbar) y de diferentes puntos peninsulares, se constata un activo comercio a larga, media y corta distancia, favorecido por el uso del caballo. 
Ritos funerarios

El calcolítico se caracteriza por el rito del enterramiento colectivo en grandes monumentos megalíticos y en cuevas naturales. Estos monumentos megalíticos parecen corresponder a sociedades igualitarias, sedentarias o transhumantes, extendiéndose por todo el territorio. Su tipología es muy variada, dividiéndose en sepulcros de corredor, cistas megalíticas, galerías cubiertas, cámaras circulares o Rundgräber, tholoi o sepulcros de cúpula y cuevas artificiales. Los sepulcros de corredor se extienden por las altiplanicies granadinas de los ríos Gor y Fardes con más de medio millar de ejemplares, por la cabecera del río Cacín y de Alhama (Bermejales), Montefrío y por la zona montañosa de Jaén, cruzando el Guadalquivir hacia Sierra Morena (La Carolina). Las cistas megalíticas son más raras, apareciendo ejemplos en el río Gor y Alhama de Granada. Las galerías cubiertas, muy escasas y de clara influencia occidental, penetran hasta la parte oriental de Málaga (Menga), los Bermejales y altiplano granadino. Los Rundgräber son propios de Almería suroriental. Los sepulcros de cúpula son característicos del sureste almeriense, penetrando débilmente en el río de Gor. Las cuevas artificiales, hipogeos que imitan al tholos, menos frecuentes que en Andalucia occidental, se localizan en Granada (Domingo Pérez, Huescar, Loja) y Jaén (Marroquies Altos), llegando hasta Castellar de Santisteban.

Las inhumaciones en ciertos monumentos llegan al doble centenar, observándose, como rito normal la inhumación con el cadáver encogido y algún indicio de cremación parcial.

\section{Arte rupestre}

Tiene lugar el apogeo del arte rupestre esquemático, iniciado en el neolítico. Se extiende intensamente en Jaén por los macizos montañosos de Sierra Morena (Despeñaperros, La Carolina) y hacia el este (Quesada, Sierra de Segura, Cazorla), penetrando en Granada (Huescar), y norte de Almería (Vélez Blanco), Macizo meridional de Jaén (Huelma, Torre del Campo, Jaén, Jabalcuz, Castillo de Locubín), macizos occidentales granadinos (Campotejar, Piñar, Iznalloz, Moclín, Montefrío) y por el Genil y río Cacín (Loja, Alhama). Los esquematismos pintados en rojo o negro y algunos grabados de la Sierra de Filabres representan antropomorfos, cuedrúpedos, idoliformes, geometrismos variados, ramiformes, esteliformes. 


\section{Hábitat}

Definitivamente el hábitat adopta el poblado de superficie, conservándose la cueva en las zonas montañosas marginales. Los poblados se extienden por todo el territorio con preferencia por las zonas Ilanas de piedemonte y valles fértiles del alto Guadalquivir, Guadiana Menor, Almanzora, Andarax, Genil y costa, asistiéndose a una multiplicación espectacular de yacimientos y a un aumento notable de la escala de los mismos, que alcanza entre media y ocho hectáreas, con un número de habitantes entre medio centenar y medio millar. Los poblados disponen de defensas naturales propiciadas por su emplazamiento elevado o destacado, y artificiales, con perímetros de murallas de piedra con bastiones semicirculares (Millares, Malagón, Castellones, Campos, Terrera Ventura, Los Alcores de Porcuna, Angosturas). El poblado mejor conocido es Los Millares con cuatro líneas defensivas, estando relacionados con él una decena de fortines circulares complejos. La urbanística es compleja con la ubicación, en el interior, de cabañas circulares o de tendencia oval esporádicamente colocadas y construidas con zócalo de piedra, muros de adobe o tapial y techumbre de ramaje sostenida por postes de madera 0 con cubierta de falsa cúpula de piedra (Almizaraque) o adobes (Cerro de la Virgen), con unas dimensiones diametrales entre $3 \mathrm{~ms}$. (Malagón) y 7 ms. (Orce). En el interior de las cabañas se disponen los hogares y bancos corridos por los muros y en el exterior proliferan los silos, fosos y trincheras para almacenes, basureros y drenaje respectivamente.

\section{Yacimientos}

Entre los inumerables yacimientos publicados destacan en Almería Los Millares (Santa Fé), El Tarajal (Nijar), Almizaraque (Cuevas del Almanzora), El Garcel (Antas), La Gerundia (Antas) Tres Cabezos (Cuevas del A.), Campos (Cuevas del A.), Oria, El Hijate, Terrera Ventura (Tabernas), Cerro de las Canteras (Vélez Blanco), Cerro de la Chinchilla (Rioja). En Granada pueden citarse El Llano de las Canteras (Alfacar), Los Castillejos (Montefrío), Malagón (Cúllar Baza), Cerro de los Castellones (Laborcillas), Cerro de los Infantes (Pinos Puenta), El Manzanil (Loja), Cerro de la Virgen (Orce), Las Angosturas (Gor), Cerro del Castellón (Campotéjar). En Jaén las recientes prospecciones han documentado El Cerro de San Marcos, La Mesa y el Castillo (Alcalá la Real), Cerro Venate, Jabalcuz, Huerto Berenguer, Torre Benzalá, Hornos de Segura, Cerro Venate (Arjonilla), Los Alcores (Porcuna), Puente Tabla, El 
Ochavo (La Carolina), La Atalaya y Cerro de la Coronilla (Cazalilla), Las Tiesas (Espelúy), Los Patos (Linares), los Pozos (Higuera de Arjona). Málaga oriental ha entregado la cueva de Nerja, Peña de Hierro, Tajo de Gomer, Los Colmenares (cuenca del río Vélez) y Morro de Mezquitilla, entre otros.

\section{Estadios}

Se había propuesto una fase de transición o cultura de Almería y otra fase plena, en función de las estructuras funerarias y de la tipología de los artefactos, según los Leisner, pero mediante las estratigrafías de los Castillejos, Terrera Ventura, Cerro de la Virgen y Almizaraque se han podido delimitar estadios.

En los Castillejos de Montefrío se ha determinado la fase de un calcolítico antiguo, de principios del III milenio y otra del pleno, de mediados del III milenio. En Los Millares con estratigrafía horizontal y con $\mathrm{C} 14$ calibrado se ha intentado deducir un primer estadio con cronología entre 3.355 y 2.905 a. C., seguido por otro todavía precampaniforme. En Terrera Ventura se han distinguido la fase I (2.850-2550 a. C.) y la ll (2.550-2.250 a. C.). En el Cerro de la Virgen, en el estrato I se han constatado dos fases precampaniformes, la $A$, que ocuparía la primera mitad del III milenio y la $B$, correspondiente a su segunda mitad. En Almizarque, igualmente, en el estrato III se han distinguido dos fases precampaniformes con una cronología análoga a la del Cerro de la Virgen.

\section{Facies regionales}

Las facies regionales se diversifican con respecto al neolítico, existiendo la de la Sierra Morena-Cazorla-Segura y María, de carácter arcaizante. En el Alto Guadalquivir y en las campiñas de Jaén se introducen desde occidente los platos, ídolos de hueso o marfil antropomorfos y los enterramientos en cueva artificial. En las sierras del sur de Jaén emerge el calcolítico con claras influencias del Bajo Guadalquivir y del este, desde Almería. En las altiplanicies granadinas proliferan los poblados amurallados con bastiones, problablemente de influencia almeriense.

En Almería oriental emergen los grandes núcleos urbanos con muralla de piedra y bastiones, cerámicas simbólicas, una industria lítica tallada de grandes foliáceos y microlitos geométricos, brazaletes de pectúnculo e im- 
portaciones de huevos de avestruz, marfil y ámbar, predominando los tipos de enterramiento "Rundgräber» $\mathrm{y}$ "tholoi». En la costa meridional siguen utilizándose las cuevas, conviviendo con poblados-talleres.

\section{CAMPANIFORME}

Región considerada

Provincias de Almeria, Jaén, Granada y Málaga oriental.

Nombre de la cultura

El fenómeno campaniforme ocupa la etapa final del calcolítico, por lo que también se le denomina eneolítico final. Es igualmente el momento de transición al bronce o cultura del Argar A, muy bien representado en las estratigrafías del Cerro de la Virgen (Orce). Tradicionalmente corresponde a la fase II B de la cultura de Los Millares o a su momento final.

\section{Datación}

El mejor exponente para la datación del campaniforme radica en el estrato o fase II del Cerro de la Virgen, cuyas cronologías absolutas, sin calibrar y calibradas, son $1.970 \pm 60$ a. C. (cal.: $2.550-2.320$ a. C.), $1970 \pm 35$ a. C. (cal.: 2.440-2.325 a. C.), $1.940 \pm 40$ a. C. (cal.: $2.430-2.305$ a. C.), $1.885 \pm 35$ a. C.(cal.: $2.410-2.190$ a. C.), $1850 \pm 35$ a. C. (cal.: 2.400-2.165 a. C.). Estas fechas inducen a creer que el campaniforme se desarrollaría en la segunda mitad del III milenio, si adoptamos una cronología calibrada, o en los dos primeros siglos del II milenio, si nos atenemos a los datos no calibrados.

Los Castillejos de Montefrío III ha fechado el campaniforme en $1.890 \pm$ 35 a. C. (cal.: 2.410-2.190 a. C.), $1.910 \pm 80$ a. C. (cal.: 2.435-2.175 a. C.) y en $1.870 \pm 50$ a. C. (cal.: $2.410-2.170$ a. C.). Terrera Ventura IV ha sido fechado entre el 2.150 y 1.950 a. C. Almizaraque II en $1.910 \pm 60$ a. C. (cal.: 2.420-2.290 a. C.). Las Angosturas de Gor en $1.910 \pm 140$ a. C. (cali.: 2.560-2.145 a. C.) y Los Castellones de Laborcillas en $1.770 \pm 40$ a. C. y $1.715 \pm 130$ a. C., sin calibrar. En consecuencia, resultando problemático precisar la cronología del campaniforme, parece plausible aceptar sus inicios hacia el 2.200/2.000 a. C. con una vigencia hasta el 1.800/1.700, sustituído por el Argar A. 


\section{CAMPANIFORME}

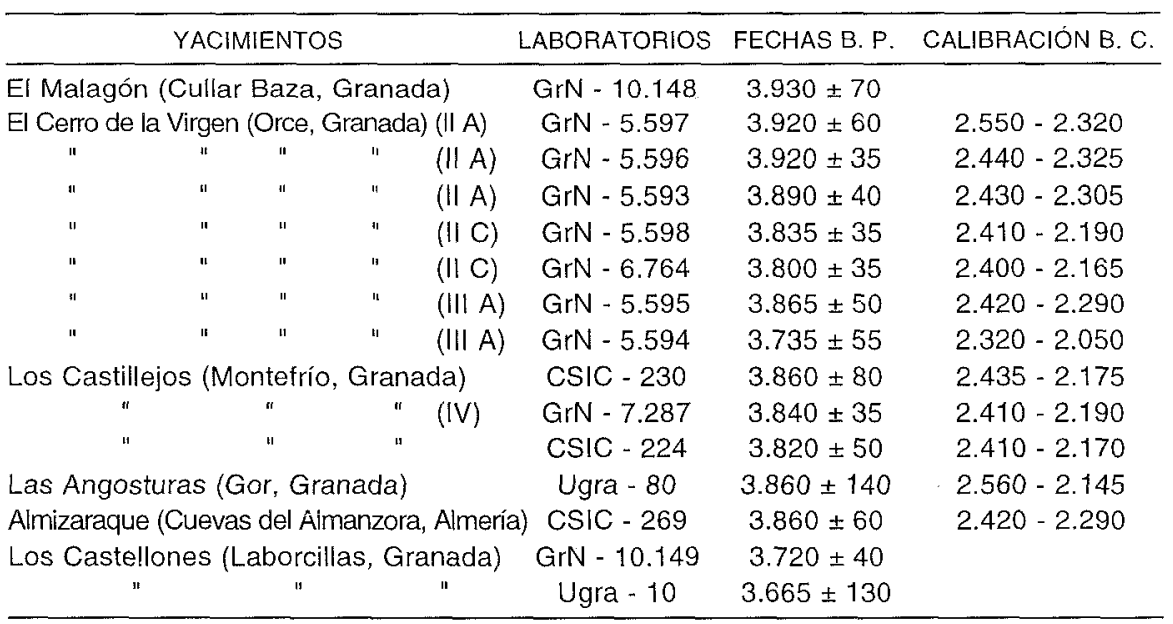

\section{Extensión geográfica}

El campaniforme ocupa sensiblemente la misma extensión geográfica que la etapa anterior del calcolítico, pero, si nos atenemos a la presencia física del vaso campaniforme, elemento intruso, observamos que su principal radio de acción corresponde a las zonas llanas próximas a los afluentes del Alto Guadalquivir (La Carolina, Úbeda, Mengíbar, Espelúy), a la campiña giennense (Arjona, Porcuna), a la altiplanicie granadina (Orce, Torrecardela, Fonelas), a la cuenca del Almanzora (Purchena, Almizaraque), a la baja cuenca del Andarax (Millares, Tabernas, Alhama) y a la costa suroriental almeríense (Gerundia, Barranquete) (figura 12).

\section{Cerámica}

La cerámica de las especies no campaniformes es análoga a la del calcolítico antiguo con ciertas variaciones en formas y decoraciones. En las formas se sigue con el predominio de las abiertas, perfil en $S$, semiesféricas, profusión de platos de borde engrosado, formas cilíndricas y troncocónicas invertidas, lenticulares, carenadas suaves que preludian las del Argar. Los pequeños vasos de beber disponen frecuentemente de ónfalo, coexistiendo con formas cerradas. En el sureste de Almería (Almizaraque) la calidad de las pastas y tratamientos es verdaderamente deficiente. Los 


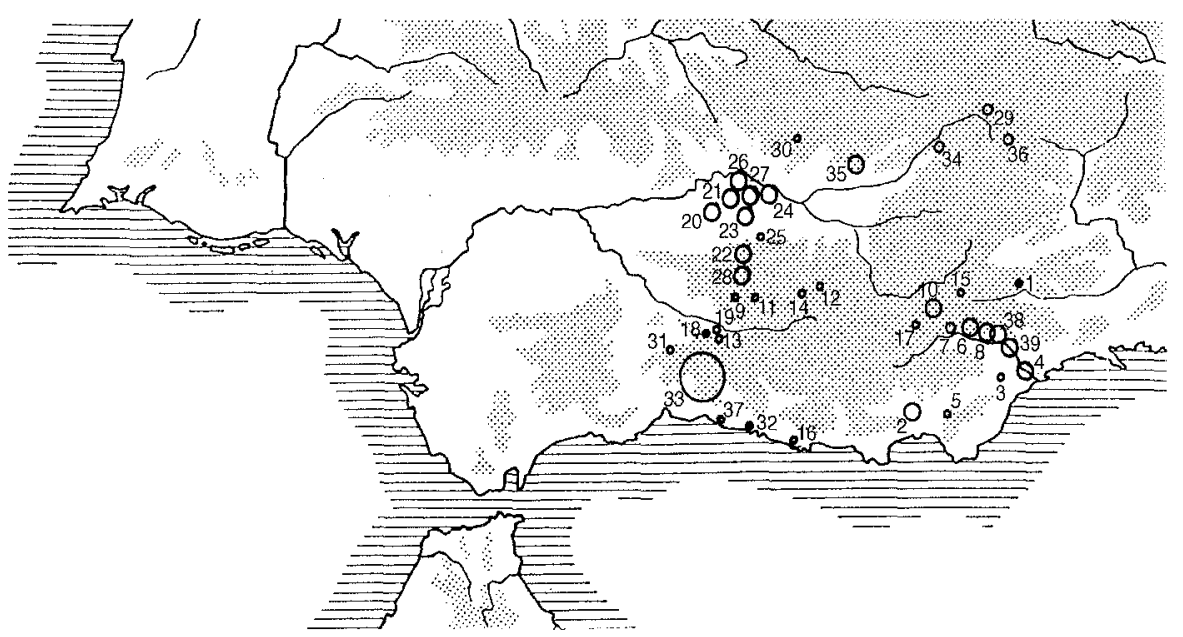

Fig. 12. Campaniforme (Finales del III milenio - Principios del II milenio) Hábitat:

Cueva ( $\bullet$. Poblado de superficie (O). Conjunto de poblados de superficie (O)

1. Cueva de Ambrosio (Vélez Blanco, Almería). 2. Conjunto de los Millares (Santa Fé de Mondújar, Almería). 3. La Gerundia (Antas, Almeria). 4. Cuevas de Almanzora (Almeria): Almizaraque. Tres Cabezos. 5. El Tarajal (Níjar, Almería). 6. Conjunto de Purchena (Almería). 7. Tíjola (Almería). 8. Conjunto de Albox (Almería). 9. Peña de los Gitanos (Montefrío, Granada). 10. Cúllar Baza (Granada): El Malagón, El Sahuco. 11. Cerro de Mingo Andrés (Moclín, Granada). 12. Cerro del Molino (Torrecardela, Granada). 13. Cortijo del Molino del Tercio (Moraleda de Zafayona, Granada). 14. Cerro de los Castellones (Laborcillas, Granada). 15. Cerro de la Virgen (Orce, Granada). 16. El Hacho (Salobreña, Granada). 17. Cerro del Puntal (Baza, Granada). 18. Cueva del Coquino (Loja, Granada). 19. El Manzanil (Loja, Granada). 20. Porcuna (Jaén): Los Alcores. Albalate, Aragonesa, Morrón. Atalaya de Lopera. Atalaya de Calatrava. 21. Conjunto de Arjona (Jaén): Cortijo de la Torre. Pachena. Villarillo, Cerro Venate (Arjonilla), Atalaya del Higuerón. 22. Conjunto de Martos (Jaén): La Nava, Bollero, Cuca, Alcázar, Arroyos, Tafu. 23. Villardonpardo/Escañuela (Jaén): Torre Benzalá, Bulario, Pedruscosas. Portichuelo. Caserío del Torrejón. Torrejón, Huerta de Antonio, Mingo López. Peón. Torrecillas. Berrueco. Peñas Rubias. Villar Viejo. Pescuezo. Marisancho. 24. Megíbar (Jaén). 25. Cerro Veleta (Jaén). 26. Espelúy (Jaén): Las Tiesas. Cortijo Líndez. Convento. 27. Cazalilla (Jaén): Atalaya. El Cerrete. Tohaires. Tajoletar. Cerro Largo, Miguelico. Guinea. Coronilla II, Atalayuelas. 28. Alcalá la Real (Jaén): Cerro de San Marcos. La Mesa. 29. Hornos de Segura III (Jaén). 30. El Ochavo (La Carolina, Jaén). 31. Peñón del Oso (Villanueva del Trabuco, Málaga). 32. Cueva de Nerja (Málaga). 33. Conjunto del Río Vélez (Málaga): Tajo de Gomer (Ríogordo). Peña de Hierro (Benamargosa). Cerro de la Capellanía (Periana). Los Colmenares. 34. Puente del Río de la Vega (Santo Tomé, Jaén). 35. Rincón de Olveda (Úbeda, Jaén). 36. Riofrío (Santiago de la Espada, Jaén). 37. Morro de Mezquitilla (Algarrobo, Málaga). 38. Conjunto de Cantoria (Almería). 39. Conjunto de Zurgena (Almería).

elementos de prehensión se reducen a memelones simples y lengüetas, con alguna asa esporádica de cinta.

Las decoraciones son extrañas, no obstante se documentan ejemplos de bordes dentados, trazos impresos o incisos, cordones, mamelones en 
el borde, pastillas repujadas, puntillados, escobillados o peinados motivos esteliformes incisos y geometrismos pintados. Es el apogeo de la cerámica simbólica de los Millares.

Con brillantez destaca la especie campaniforme con predominio del tipo marítimo o puntillado, primero en aparecer, y el tipo Cienpozuelos o continental, de constante presencia, y, en menor escala, el inciso o tipo Palmela, más reciente. Existe un tipo llamado almeriense decorado por paralelas flanqueadas por zigzags.

Industria lítica

La industria lítica tallada sigue las pautas anteriores, aunque menos diversificada, con predominio de las láminas dentadas, llamadas dientes de hoz o sierras, las láminas con muescas, con retoque continuo y grandes láminas sin retoque. Los foliáceos o puntas de flecha alcanzan su apogeo, siendo comunes y casi exclusivas las de aletas y pedúnculo y romboidales en la parte de Almería oriental. Las triangulares son más escasas y las de base cóncava muy raras, cuyo origen es occidental. La industria lítica pulimentada continúa, decreciendo las hachas con tipología más plana y aumentando las azuelas, sin que falten alisadores y grandes martillos de minero, ovoides con ranura central.

\section{Industria ósea}

La industria del hueso se empobrece, aunque no la relativa a adornos y figuritas o idolillos antropomorfos. Los punzones de metápodos son más toscos, continuando las grandes espátulas, las agujas de ancha cabeza planas y las agujas con ojo.

\section{Metalurgia}

Los artefactos de cobre, que simplemente habían hecho acto de presencia en la etapa anterior, se generalizan sin que logren desplazar a la industria lítica. Son normales los puñales de lengüeta trapezoidal (Castillejos III), puñales con escotaduras laterales (Villacarrillo, Las Tiesas, Orce), cuchillos de hoja curva (Castillejos), diversos tipos de punzones de sección circular y cuadrada y las puntas de fecha tipo Palmela, consideradas como fósil característico. Esta industria sería objeto de comercio, 
surgiendo centros principales de metalurgia con abundancia de hornos, escorias, crisoles y moldes (Almizaraque).

\section{Adornos}

La diversificación de elementos ornamentales personales, derivados de tipos anteriores, alcanzan su auge con algunas novedades materiales y formales, fabricadas con piedras semipreciosas, como amatista (Millares), piedras verdes (Millares, Almizaraque, Fonelas), azabache (Millares), conchas, hueso, marfil (Millares, Almizaraque, Guadix, Purchena), huevo de avestruz (Millares), ámbar (Millares, Guadix), cerámica (Tabernas), cobre (Millares) y oro (Mojácar). El tipo más frecuente es la cuenta de collar y el colgante de forma anular, tubular, discoidal, cilíndrica, troncónica, toneliforme, segmentada y diferentes conchas marinas perforadas.Muy característicos son los brazaletes de arquero de piedra rectangulares con perforaciones en los extremos. Los botones de hueso y marfil con perforación en $V$ diversifican los tipos con nuevas formas piramidales, cónicas, prismáticas triangulares y de tortuga. Los peines de hueso y marfil son más frecuentes (Purchena, Millares). Adornos de función funeraria son las sandalias de mármol y marfil de Almizaraque y Los Millares. Las pulseras son de pectúnculo y marfil (figura 13).

\section{Economía}

El clima del campaniforme, condicionante de la economía, corresponde al final del período atlántico, menos cálido y húmedo. Se desarrollan ciertas especies vegetales, como el esparto (Rioja, Garcel), alcornoque y encina (Nerja, Almizaraque), acebuche (Nerja, Garcel Millares), pino (Millares), álamo (Almizaraque), fresno (Millares), castaño (Millares). La agricultura de secano está en pleno apogeo, representada por el trigo común, muy abundante (Nerja, Almizaraque, Malagón, Castillejos, Tabernas), cebada (Nerja, Almizaraque) y centeno (Garcel). Entre las gramíneas tenemos el haba (Almizaraque, Garcel), arbeja (Nerja), lenteja (Campos) y, junto a los ríos, el lino (Orce, Almizaraque). Quizás se utiliza el arado tirado por bueyes y caballos (Orce, Campos, Castillejos, Barranquete). Los excedentes de las cosechas se conservan en los silos (Garcel, Millares Orce, Tabernas, Malagón).

En cuanto a la fauna, predomina abrumadoramente la doméstica, que en Los Castillejos, con un $67 \%$, se compone de ovicápridos, bóvidos, 

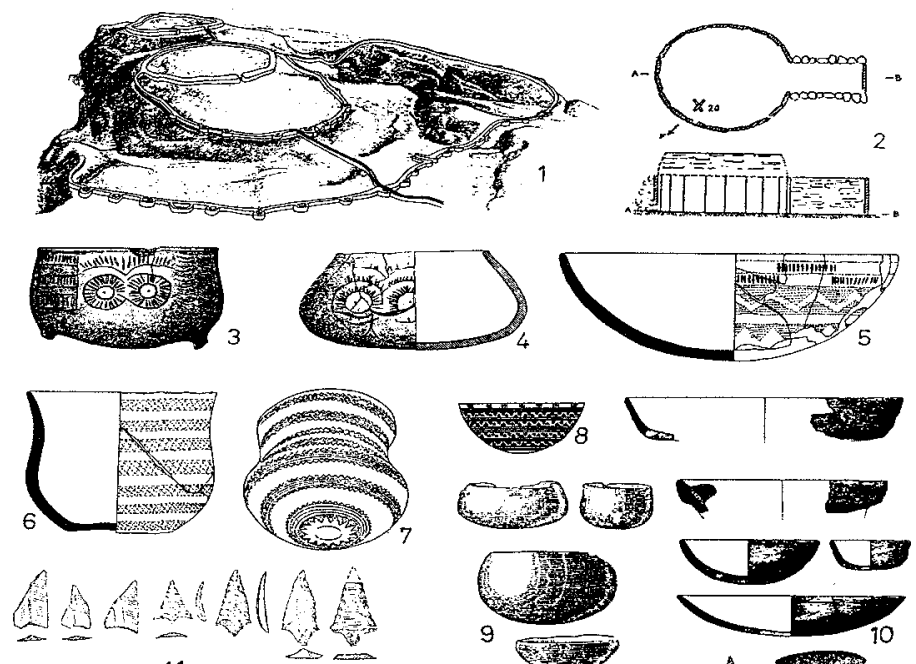

11
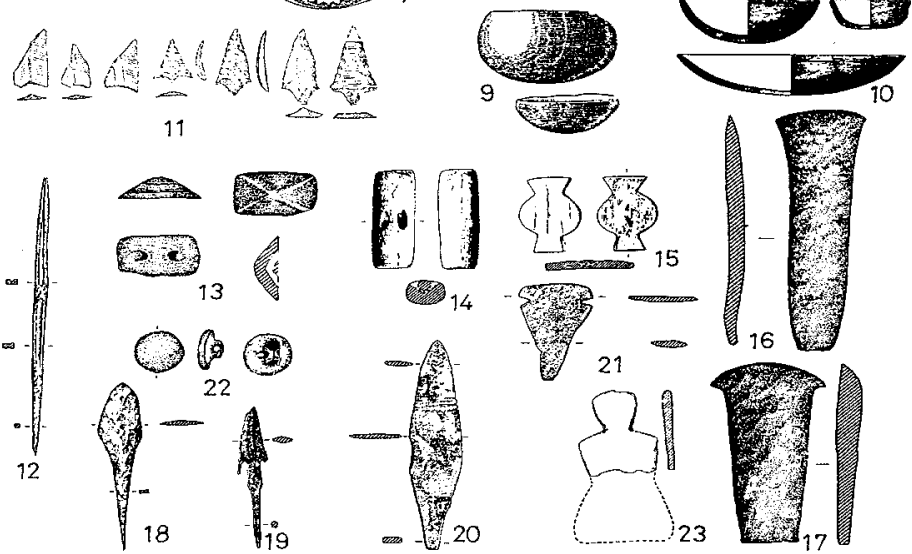

Fig. 13. Campaniforme.

1. Recintos fortificados de Los Millares. 2. Tholos. 3. Vaso polípodo con decoración incisa simbólica. 4. Vaso troncocónico con decoración incisa simbólica. 5. Cuenco campaniforme inciso y puntillado. 6. Vaso campaniforme puntillado marítico. 7. Vaso campaniforme tipo almeriense. 8. Cuenco campaniforme inciso y estampillado. 9. Cuencos lisos. 10. Cuencos y platos diversos. 11. Geométricos y puntas de flecha de silex. 12. Punzón doble de cobre. 13. Botón piramidal con perforación en $\mathrm{V}$, de marfil. 14. Botón de sección oval con perforación en $\mathrm{V}$, de marfil. 15. Botón de tortuga con perforación en $V$ de marfil. 16. Hacha rectangular de cobre. 17. Hacha rectangular de cobre con filo curvo. 18. Punta de flecha de cobre tipo Palmela. 19. Punta de flecha de aletas y largo pedúnculo de cobre. 20. Punta de lanza romboidal de cobre. 21. Puñal con escotaduras laterales de cobre. 22. Botón discoidal de oro. 23. Ídolo triangular de hueso.

Procedencia:

1, 3, 4 y 9: Los Millares (Santa Fe de Mondújar, Almería). 2 y 7: Loma de la Atalaya (Purchena, Almería). 5: El Barranquete (Níjar, Almería). 6: Loma de Belmonte (Mojácar, Almería). 8: El Argar (Antas,Almería). 10: Almizaraque (Cuevas del Almanzora, Almería). 11 y 23: Rambla de Huechar (Alhama de Almería). 12, 16 y 18: Sierra Martilla (Loja, Granada). 13 y 22: Covacha de la Presa (Loja, Granada). 14, 15, 19-21: Los Castillejos (Montefrío, Granada).

1: según A. ARRiBAs. 2-4, 6, 7, 9, 11 y 23: según G. y V. Leisner. 5: según M. ${ }^{a}$ J. Almagro. 8 : según H. y L. Siret. 10: según G. Delibes. 12, 13, 16-18 y 22: según J. Carrasco. 14, 15, 1921: según M. TARRADELL. 
cerdo y perro, estando constituída la salvaje por ciervo, corzo, jabalí y conejo. En yacimientos costeros como Nerja juega especial importancia la ictiofauna y la malacofauna, compuesta ésta, en orden decreciente, por monodonta $(57 \%)$, patella $(19 \%)$, thaïs $(10 \%)$, mytilus $(6 \%)$ caracol terrestre $(4 \%)$ y glycymeris $(6 \%)$. La cerámica se cuece en hornos de cúpula (Almizaraque, Malagón) y el queso se fabrica en vasos perforados. La industria textil está en pleno apogeo. El comercio a larga distancia prosigue vigoroso con África (marfil, huevos de avestruz) y el Atlántico (ámbar).

\section{Ritos funerarios}

El enterramiento prosigue colectivo en cueva en las zonas montañosas retardatarias (Nerja, Carigüela, La Presa, Río Frío) y en megalitos, generalmente reutilizando los de la etapa anterior, añadiendo nichos supletorios. Continúan las cuevas artificiales. Estos enterramientos siempre van acompañados de abundante ajuar cerámico, lítico, óseo, metálico y especialmente de ídolos diversos análogos a los de la etapa anterior.

\section{Arte rupestre}

En los abrigos rocosos se continúa pintando figuras esquemáticas, cuya cronología se deduce de análogas representaciones de la cerámica simbólica y campaniforme (La Carolina, Millares) y por los grabados de ciertos dólmenes (cáprido de Montefrío). Su distribución y temática es continuación de la anterior, con especial protagonismo del cérvido, ramiforme y esteliforme. A este momento podrian corresponden algunos grabados petroglifoides de Almería (Gergal, Tahal).

\section{Hábitat}

Se asiste a una concentración demográfica, ampliando algunos establecimientos (Orce II, Millares III, Malagón II), con diámetros de más de cien metros, en detrimento de otros desaparecidos. Las fortificaciones pierden la monumentalidad y calidad anterior. En Orce se reduce a una especie de «agger» con foso, talud de tierra sostenido por troncos. En Los Millares se construye el tercero y cuarto recinto con paramentos dobles, rellenos de piedras, con torres huecas adosadas semicirculares y ovales. 
En Puente del Río de la Vega (Santo Tomé) se levanta el recinto exterior. En el Cerro de los Castellones de Laborcillas se refuerza la muralla. con bastiones.

Las viviendas siguen la pauta anterior con algunas variaciones. En el Cerro de la Virgen II B-C las cabañas adoptan un diámetro menor, siguiendo la técnica del adobe de muros cilíndricos y techo de ramaje, desapareciendo la falsa cúpula. En el Malagón II A-B aumenta el diámetro de las casas entre 4,2 y 6 metros, con postes de sustentación, suelo apisonado y posiblemente con falsa cúpula, como anteriormente sucedía en Orce, empleándose el embutido de postes en los muros. En el momento final de Los Millares III, con chozas circulares. En Almizaraque III A, las casas de falsa cúpula se construyen con grandes cantos rodados. Tímidamente se va imponiendo la casa de estructura más firme con la lenta adopción de la planta rectangular de piedra con extremos redondeados (Terrera Ventura III, Almizaraque II B-A, Castillejos I). Prosiguen los silos, hornos y muros divisorios entre las viviendas.

\section{Yacimientos}

Ciertos pequeños establecimientos anteriores son absorbidos por otros de mayor escala, fenómeno estudiado en la campiña giennense, donde se ha tratado de confeccionar unos polígonos de asentamientos jerarquicos con núcleos principales, según la teoría del lugar central. Se consideran núcleos principales por su emplazamiento y escala, Albalate (Porcuna), Arjona, Atalaya de la Higuera (Arjona), Las Tiesas (Espelúy), La Nava (Martos), Torre Benzalá (Villardonpardo), Villagordo y Atalayuelas (Cazalilla).

\section{Estadios}

El yacimiento clave para periodizar el campaniforme es el Cerro de la Virgen de Orce, donde su estrato II ha sido dividido en tres subestratos, $A$, $\mathrm{B}$ y $\mathrm{C}, e$, incluso, el subestrato II A pudo, a su vez, subdividirse en tres fases internas (1, 2 y 3 ). Estas fases, según el C14 sin calibrar, discurrirían entre 1.970 y 1.785 a. C. y, calibrado, entre 2.550 y 2.165 a. C. En los Castillejos de Montefrío el campaniforme ocuparía las fases IV (estrato III) y $V$ (estratos I! y I), con una cronología entre 2.300 y 1.800 a. C. En Almizaraque el estrato II, con campaniforme, pudo dividirse en cuatro niveles o fases $(D, C, B, A)$, con una cronología paralela a la de Orce. 


\section{Facies regionales}

No es posible en el estado actual de las investigaciones distinguir facies regionales específicas del campaniforme, por lo que nos atendremos a las ya propuestas en la etapa anterior. No obstante, como hipótesis de trabajo, podrian proponerse la facies de Almeria con las cuencas de los ríos Almanzora, Aguas y Andarax, una segunda facies con los altiplanos granadinos y el peculiar yacimiento de Orce. Otra facies podrían entreverse en la cuenca alta del Genil y otra en la campiña giennense y alto Guadalquivir.

\section{EL NEOLITICO Y CALCOLITICO EN ANDALUCIAA ORIENTAL: SINTESIS}

Con las teorías difusionistas de la primera mitad del sigio xx, la emergencia del neolítico y calcolítico en Andalucía oriental se explicaban buscando raíces externas en Oriente y África. Estas teorías difusionistas han perdido vigencia o se han suavizado notablemente, entreviéndose en el Mediterráneo occidental un gran círculo del neolítico antiguo de las cerámicas impresas cardiales y un calcolítico autóctono, que toma ideas comunes en todo el mar interior. Gracias a la ayuda de las dataciones radiocarbónicas ha sido necesario modificar las viejas teorías y considerar la emergencia del neolítico de Andaludía oriental como un producto de evolución del anterior sustrato epipaleolítico, habiendo jugado un papel preponderante en su formación el círculo levantino de la cerámica cardial, inmerso en el Mediterráneo noroccidental, y el círculo del suroeste peninsular de la cerámica a la almagra, cuya anterioridad cronológica está suficientemente constatada.

Respecto al calcolítico, el círculo del sur de Portugal y especialmente el del Alto Alentejo protagonizará con su clara influencia la formación de la nueva cultura, aparte de la adopción de nuevas ideas mediterráneas por una sociedad culturalmente avanzada y preparada.

Como región específica, Andalucía oriental, formada por las provincias de Almería, Jaén, Granada y Málaga, a pesar de su carácter montañoso con respecto a la occidental, no responde a una unidad geográfica ni cultura! ni en la prehistoria ni en la historia. Suis facies culturales están en función de la geografía, de los accidentes orográficos e hidrográficos, determinantes de los contactos humanos, que cruzan diagonalmente la región desde el noreste hacia el suroeste, surgiendo seis comarcas o subcírculos con características culturales específicas en la prehistoria. Estos subcírculos serían A) 
La Sierra Morena, al norte del alto Guadalquivir. B) El alto valle del Guadalquivir con las campiñas giennenses. C) La Cordillera Subbética, cortada de norte a sur por el Guadiana Menor. D) La altiplanicie granadina y el alto Genil. E) El Sistema Penibético con la costa meridional, excluida la parte occidental de Málaga, F) El sureste de Almería.

Las diferentes culturas $u$ horizontes culturales con sus respectivas fases han recibido diversas terminologías, según el estado de las investigaciones. El neolítico antiguo y medio se conoció como cultura de las cuevas, hispano-mauritano, neolítico I y neolítico de la cerámica impresa o cardial. Parece más correcto denominar al neolítico antiguo, según sus cerámicas impresas y a la almagra, y al medio, según sus cerámicas incisas. Al neolítico final no parece adecuado llamarlo restringidamente cultura de Almería, ni neoeneolítico por genérico, ni iberosahariano por ilusorio, sino neolítico de las cerámicas lisas. Al calcolítico no es procedente darle el apelativo de cultura de los Millares, por restrictivo, ni bronce I, por erróneo, sino más bien precampaniforme, para distinguirlo de su fase final, ya campaniforme.

Hasta los años sesenta, era creencia común fechar los inicios del neolítico hacia el 3.000 a.C., pero la datación radiocarbónica de la Cueva de l'Or en Levante destruyó la estructura cronológica, obligando a subir las fechas en más de dos milenios. En la actualidad las cronologías obtenidas en las cuevas de Nerja, el Nacimiento de Pontones y de los Murciélagos de Albuñol inducen a colocar la emergencia del neolítico en Andalucía oriental, al menos, en la segunda mitad del vı milenio a.C. y el neolítico final entre mediados del iv y la primera mitad del III milenio a.C., según Nerja, Murciélagos del Albuñol y Terrera Ventura de Tabernas. Incluso, han podido también establecerse subfases o estadios en función de las estratigrafías de Nerja, Carigüela y Castillejos de Montefrío. Del calcolítico precampaniforme se han obtenido dataciones radiocarbónicas en la cueva de Nerja, en los poblados de Terrera Ventura, Almizaraque, Los Millares, Tarajál, Las Angosturas y Malagón y en los «tholoi» del Barranquete, habiéndose logrado establecer subfases en las estratigrafías de los Castillejos, Millares, Terrera Ventura, Cerro de la Virgen y Almizaraque, con una cronología que va desde el primer cuarto del III milenio a.C. hasta el 2200/200 a.C., utilizando fechas sin calibrar. El campaniforme ha sido encuadrado en la fase II del Cerro de la Virge, III de los Castillejos, IV de Terrera Ventura, II de Almizaraque y, además en el Tarajal, Angosturas y Castellones de Laborcillas, siendo plausible colocar esta fase del calcolítico final campaniforme entre el 2200/2000 y el 1700 a.C., utilizando dataciones sin calibrar. De igual modo, dentro del campaniforme se han delimitado estadios en las estratigrafías del Cerro de la Virgen, Castillejos, Almizaraque, Millares y Cueva de Nerja. 
La cerámica sigue siendo el fósil característico de las diferentes culturas, y, de esta manera, es detectado el neolítico antiguo de Andalucía oriental por sus cerámicas cardiales de influencia levantina $y$, en su fase avanzada de este neolítico, por las tratadas a la almagra, de influencia del bajo Guadalquivir y Subbética occidental, con elegantes motivos geométricos incisos e impresos. El neolítico medio, decaída la cardial, se caracteriza por el apogeo de la cerámica a la almagra y especialmente por la técnica decorativa incisa, formando complicadas composiciones geométricas rectilíneas y curvilíneas, con diversificación de formas y de elementos de suspensión como las asas multiforadas, de pitorro y de apéndices. Con el neolítico final la decoración pierde entidad y los galbos tienden a abrirse y a adquirir formas agudas en $Z$, con bordes fuertemente indicados. Con el calcolítico los vasos aumentan de tamaño, las pastas y tratamientos son más toscos y las formas se abren definitivamente con la aparición, en la parte oeste de la región, de grandes platos carenados, sustituídos paulatinamente y en todo el territorio por los de borde engrosado o almendrado, siendo muy parcas las decoraciones. Con el campaniforme prosigue gran parte de las formas evolucionadas, con ejemplos de decoraciones simbólicas, que conviven con la especie intrusa del vaso campaniforme de tipo marítimo, Palmela y Ciempozuelos, de aparición sucesiva, frecuente en los habitats y en los enterramientos megalíticos.

La industria lítica tallada en el neolítico antiguo es de tradición epipaleolítica, de tipo microlaminar, con variedades de raspadores, buriles, bordes abatidos, denticulados, fracturas y escasez de geométricos, perviviendo en el neolítico medio. Con el neolítico final se debilita esta diversificación, aumentando de tamaño las láminas, producidas en grandes cantidades en los talleres al aire libre, aumentando la proporción de geométricos. En el calcolítico aparecen las grandes piezas o macroindustria, ocupando lugar preferente las grandes láminas y lascas retocadas. Se documentan por vez primera los foliáceos, tanto en macroindustria de puñales y alabardas, como en microindustria de tipos diversos de puntas de flecha de aletas y pedúnculo, romboidales y triangulares, resurgiendo espectacularmente los geométricos trapezoidales y triangulares. En la etapa campaniforme son frecuentes las láminas dentadas o dientes de hoz, prosiguiendo con más intensidad los foliáceos o puntas de flecha, con rareza de las de base cóncava, propias de Andalucía occidental. Los pulimentados son escasos en el neolítico antiguo, más abundante en el medio, con tipos de hachas de sección redondeada, hachitas y azuelas, llegando a su apogeo en el final y prosiguiendo en el calcolítico. Los molinos, moletas y machacadores, aunque presentes en el neolítico antiguo y medio, por estar generalmente manchados de ocre, parece que no tuvieron especial función en 
la molienda de cereales. Estas piezas se presentan sin teñir a partir del neolítico final.

En cuanto a la industria ósea predomina en el neolítico y calcolítico el punzón sobre metápodo de ovicáprido y el de media caña sobre hueso largo, a la vez que las espátulas sobre costillas. En el neolítico final se inicia el punzón-espátula plano con ancha cabeza y el tensador textil o separador de cuentas de collar, que proseguirán en el calcolítico junto con variedad de agujas, varillas, leznas, alfileres con cabeza cilíndrica estriada y los peines.

El elemento de adorno personal más llamativo, el brazalete o tobillera de mármol, se inicia en el neolítico antiguo, sin estrías, evolucionando en el medio, con anchos ejemplares estriados, cuyo origen habría que buscarlos en la vertiente sur de la Penibética, y terminando en el neolítico final. Paralelamente coexisten los brazaletes de pizarra, negros, en forma de aro o corona circular. El neolítico medio significa el apogeo del adorno personal con variedad de anillos de hueso, tubitos, cuentas diversas de piedra, concha y dientes perforados, disminuyendo en el neolítico final. El brazalete de pectúnculo sustituye a los líticos a partir del neolítico final, aumentando su número en el calcolítico, momento en que surgen nuevas formas de adornos con materias exóticas, como el marfil, huevo de avestruz y ámbar, cuyo apogeo estará en el campaniforme con los típicos y variados botones de huesos y marfil, con formas semi-esféricas, cónicas, piramidales, prismáticas triangulares y de tortuga, siendo normales los peines.

En los inicios del calcolítico parece que todavía no se trabaja cobre, pero ya existen unas formas culturales de explotación de recursos, unas estructuras de habitat y enterramientos, ritos funerarios y artefactos en general, indicativos de un nuevo género de vida, de una inovada cultura y sociedad, que perdurará un milenio con una floreciente economía agraria, interfiriéndose, según las zonas, con el Argar A. La débil metalurgia del calcolítico se generaliza en el campaniforme con una variada panoplia de punzones, cuchillos curvos, escoplos, hachas planas trapezoidales, puñales de lengüeta y de escotaduras laterales, sierras y puntas de flecha tipo Palmela. Esta nueva industria no influyó apenas en el cambio de la economía calcolítica por su insignificancia de producción.

La base de la subsistencia en el neolítico es la dieta animal, tanto salvaje como doméstica, predominando la primera en zonas agrestes y montañosas del interior. Las especies de fauna doméstica en el neolítico y calcolítico son, en sentido decreciente, el ovicáprido, el bóvido y el cerdo. En la costa la ictiofauna y malacofauna juegan un importante papel en la alimentación, con porcentajes muy altos, consumiéndose intensamente la "patella». 
La agricultura cerealística, explotada ya en el neolítico antiguo del Levante, según la cueva de l'Or, se iniciaría en la Carigüela ya en el neolítico antiguo, en la cueva del Toro (Antequera) en el neolítico medio y en la de Nerja en el final. El hecho de que los artefactos de molienda del neolítico antiguo y medio aparezcan manchados de ocre hacen presumir su langidez. Las especies cultivadas son diferentes clases de trigo en el neolítico, las habas y lentejas desde el neolítico final, el centeno y lino desde el calcolítico y la arbeja desde el campaniforme. Desde el neolítico se consumen gran cantidad de bellotas, piñones y olivas, la vid desde el neolítico final. La gran cantidad de cereales, conservados en los silos que cubren los poblados calcolíticos y sus emplazamientos en zonas fértiles de valles y campiñas, son testimonio del gran auge adquirido por la agricultura, sin que esté suficientemente comprobado el regadío, ni en Orce ni en los Millares, cuyas acequias estarían en función del servicio de los poblados.

Probablemente desde el calcolítico se explotó el buey y el caballo como animales de tiro del arado y de carga. El comercio, muy débil en el neolítico, efectuado a distancias cortas con un máximo de $200 \mathrm{kms}$., según documenta la petrografía de ciertos artefactos, se amplía en el calcolítico y campaniforme a largas distancias, que alcanzan miles de kilómetros hasta el norte de Africa (marfil y huevos de avestruz) y el Báltico (ámbar).

El enterramiento en el neolítico es individual, con el cadáver en posición encogida y sin ajuar aparente, efectuado normalmente en las mismas cuevas de habitación. En el calcolítico se introduce el enterramiento colectivo, tanto en cuevas como en grandes monumentos funerarios, dispersos, si pertenecen a poblaciones ganaderas transhumantes, y concentrados, si corresponden a las necrópolis de los poblados, como los Millares, Barranquete o Montefrío. Estos enterramientos, según su tipolotía, pueden ser sepulcros de corredor (Altiplanicies granadinas, río de Alhama, Montefrío, Jaén), cistas megalíticas (Río Gor, Alhama), galerías cubiertas (Antequera, Bermejales, altiplano granadino), «Rundgräber» o cámaras circulares (sur-este de Almería), «tholoi» o de falsa cúpula con corredor (sureste de Almería) y cuevas artificiales (altiplano granadino, Genil y Jaén), perdurando, frecuentemente reutilizados en el campaniforme. Estos sepulcros, generalmente megalíticos, llegan a contener, en ocasiones, cerca de dos centenares de inhumaciones con indicios de cremación parcial de algunos individuos, siempre acompañados de abundante y variado ajuar.

El arte rupestre es de tipo esquemático, prevaleciendo la pintura frente al grabado, en abrigos rocosos. Parece que este arte se inicia ya en el neolítico antiguo, existiendo documentos cerámicos del neolítico medio 
(Prado Negro, Nerja, Carigüela, Carburero, La Mujer, Salar), en que se representan ramiformes, esteliformes y antropomorfos. Al neolítico antiguo/medio deben pertenecer los motivos seminaturalistas de Sierra Morena oriental, Sierra de Segura, círculo de Quesada y Vélez Blanco. Los fragmentos cerámicos del neolítico final de Nerja, con motivo esquemáticos de cabras monteses, sirven igualmente para fechar el arte rupestre. En el calcolítico y campaniforme la pintura rupestre esquemática alcanzaría su apogeo, si la contrastamos con los motivos de las cerámicas simbólicas y con los grabados de ciertos dólmenes tardíos de Montefrío.

El habitat esencial de neolítico es la cueva, pero conforme aumenta la intensidad de las prospecciones, van apareciendo emplazamientos de superficie, de pequeño tamaño, que no alcanzan la hectárea, como el Llano de las Canteras (Alfacar), La Molaina (Pinos Puente), Las Catorce Fanegas (Moclín), Cerro de las Animas (Vélez Blanco) y Ciavieja (Dalías). En el neolítico medio se inician otros poblados como Los Castillejos de Montefrío y una serie de poblados-talleres de la cuenca del río Vélez. En el neolítico final tiene lugar la eclosión de los yacimientos de superficie, habiéndose documentado más de una veintena, que se extienden preferentemente por las zonas llanas giennenses, altiplano granadino y sur este de Almería.

Con el calcolítico el habitat adopta definitivamente la modalidad del poblado de superficie, aconteciendo una de las mayores eclosiones demográficas de la prehistoria. Si los poblados se multiplican, la escala de los mismos aumenta considerablemente, alcanzando hasta ocho hectáreas, con una población en cada uno que oscila entre medio centenar y medio millar de habitantes. Los poblados se revisten de defensas artificiales con murallas de piedra, en ocasiones, múltiples (Los Millares), flanqueadas por bastiones circulares o semicirculares (Millares, Malagón, Castellones, Terrera Ventura, Angosturas) y protegidos a distancia por complejos fortines circulares (Millares, Malagón). En el interior de los poblados se levantan esporádicamente viviendas de planta circular u oval con zócalos de piedra, muros de adobe o tapial, postes de sustentación y suelos apisonados. Existen ejemplos de casas de piedra de falsa cúpula (Almizaraque) o de adobe (Cerro de la Virgen). Su interior dispone de hogares y bancos pegados a los muros, con función de vasares, abriéndose en la superficie de los poblados complejas estructuras de fosos, trincheras y silos para drenaje, basureros y almacenes, combinándose con cercas de piedras divisorias. En el campaniforme se efectúan los primeros ensayos de la casa de piedra de planta rectangular (Terrera Ventura III, Almizaraque II, Castillejos) que preludian las estructuras rectilíneas del Argar. 
Hacia el 1800 se marca el momento de transición al bronce con profundos cambios en el habitat, enterramiento, artefactos y en suma, en la sociedad y economía.

\section{BIBLIOGRAFIA}

Acosta, P., 1968: La pintura rupestre esquemática en España. Universidad de Salamanca.

Acosta, P., 1976: Excavaciones en el yacimiento de El Garcel (Antas, Almería). Not. Arq. Hisp. 5. Madrid, 187 y s.

AcostA, P., 1984: El arte rupestre esquemático ibérico: Problemas de cronología preliminar. Scripta Praehistorica F. Jordá Oblata. Salamanca, 31-62.

Acosta, P. y Cruz-Auñon, R., 1981: Los enterramientos de las fases iniciales en la cultura de Almeria, Habis 12. Sevilla, 275-360.

Aguayo, P. 1977: Construcciones defensivas de la edad del cobre peninsular. El Cerro de los Castellones (Laborcillas, Granada). C.P.U. Granada, 2, 87-104.

AlfARO, C. 1980: Estudio de los materiales de cestería procedentes de la Cueva de los Murciélagos (Albuñol, Granada). Tr. Preh. 37. Madrid, 109-162.

ALMAGRo BASCH, M. y ARRIBAS, A., 1963: El poblado y la necrópolis megalíticos de Los Millares, Santa Fe de Mondujar (Almeria). Bibl. Praeh. Hisp. III. Madrid.

Almagro Gorbea, M. J., 1973: Los idolos del bronce / hispano. Bibl. Praeh. Hisp. XII. Madrid.

Almagro Gorbea, M.J., 1974: El poblado y la necrópolis del Barranquete (Almeria). Acta Arch. Hisp. 6. Madrid.

Almagro Gorbea, M.J., 1976: Memoria de las excavaciones efectuadas en el yacimiento de $E$ Tarajal (Almería). Not. Arq. Hisp., Preh. 5, Madrid, 193-214.

ARRIBAS, A., 1976: Las bases actuales para el estudio del eneolítico y la edad del bronce en el sudeste de la Península Ibérica. C.P.U. Granada, 1, 139-155.

ARRiBAS, A., 1986: La época del cobre en Andalucía oriental: Perspectivas de la investigación actual. Hom. a L. Siret. Madrid, 159-166.

ARriBAs, A. y otros, 1978: El poblado de la edad del cobre de El Malagón (Cúllar Baza, Gianada), C.P.U. Granada, 3, 67-116.

Arribas, A. y Molina, F., 1979: El poblado de Los Castillejos en Las Peñas de los Gitanos (Montefrío, Granada). El corte 1. C.P.U. Granada, 3.

ARRIBAS, A. y otros, 1981: Excavaciones en Los Millares (Santa Fe de Mondújar, Almería). C.P.U. Granada 6, 91-122.

Asquerino, M.D., 1983: Una aproxímación a la paleoecología del neolítico: La Cueva del Nacimiento (Pontones, Jaén). Hom. Prof. M. Almagro, 1, Universidad de Madrid, 431 y sig.

Asquerino, M.D., 1987: El neolítico en Andalucía: Estado actual-del conocimiento. T. Preh. 44.

Asquerino, M.D. y Carrasco, J., 1978: Neolítico en la provincia de Jaén. C.P.U. Granada, 345 y ss.

Asquerino, M.D. y LóPez P., 1981: La cueva del Nacimiento (Pontones). Un yacimiento neolítico en la Sierra de Segura. T. Pre. 38. Madrid, 109-152.

AтосHE, P., 1987: La cerámica a la almagra en las cuevas de Andalucia oriental. Univ. La Laguna.

BeRdichewskY, B., 1964: Los enterramientos en cuevas artificiales del bronce I hispánico. Bibl. Praeh. Hisp. VI, Madrid.

BLANCE B., 1971: Die Anfänge der Metallurgie auf der lberischen Halbinsel. S.A. M, 4 Berlín.

BOESSNECK, J. und DIRESCH A, von den, 1980: Tierknochenfunde aus vier südspanischen Höhlen. Studien über frühe Tierknochenfunde von der lberischen Halbinsel, 7 München, 1-35.

Bosch, P., 1935: Explotación de yacimientos argentíferos en ej eneolítico en Almizaraque (Almería). Inv. y Progreso, IX, 4. Madrid, 112-117.

$\mathrm{Bosch}$, P., 1969: La Cultura de Almería. Pyrenae 5, Barcelona, 7-93.

BotelLA, M., 1981: Excavaciones arqueológicas en el poblado eneolítico de las Angosturas (Gor). Bol. Diputación Prov. Granada, 6, 123-166.

CARRASCO, J. y otros, 1980: Aproximación al problamiento eneolítico en el Alto Guadalquivir. Publ. Museo de Jaén, 8, Maracena. 
Carrasco, J. y otros, 1982: Las pinturas rupestres del Cerro del Piorno (Pinos Puente, Granada). Consideraciones sobre el arte rupestre esquemático en las sierras subbéticas andaluzas. C.P.U. Granada, 7, 113-169.

CarRasco, J. y otros, 1987: Las Catorce Fanegas. Un yacimiento neolítico al aire libre. Rev. Centro Est. Hist. de Granada y su Reino, 1, $2^{2}$ época, 9-36.

CarRión, F. y Contreras, F., 1979: Yacimientos neolíticos en la zona de Moclín, Granada. C.P.U. Granada, 4, 21-56.

ChAPMAN, R., 1981: Los Millares y la cronología relativa del eneolítico en el sudeste de España. C.P.U. Granada, 6, 75-89.

DELIBES, G. y otros, 1986: El poblado de Almizaraque. Homenaje a L. Siret, Madrid, 167-177.

DRIESCH, A. VON DEN y MORALES, A., 1977: Los restos animales del yacimiento de Terrera Ventura (Tabernas, Almería). C.P.A.U.A. Madrid, 4, 15-34.

DRIESCH, A. VON DEN und KOLABI, M., 1977: Tierknochenfunde aus der Siedlung Cerro de los Castellones bei Laborcillas/Granada. Archäologie und Naturwissenschaften 1, 129-143.

Fernández-Miranda, M. y Delibes, G., 1982: Almizaraque. Arqueología, 81. Madrid 29 y ss.

FERnÁndez-MirAnda, M. y otros, 1987: El poblado neolítico de Cuartillas en Mojácar (Almería). An. Arq. Andalucia, III, Sevilla, 31-35.

FERRER, E., 1981: Los sepulcros megaliticos de la provincia de Granada. Univ. de Granada, 520.

FERRER, E., 1986: El megalitismo en Andalucía oriental: Problemática. Mesa Red. sobre Megalitismo Peninsular. Madrid, 97-110.

FERRER, E., 1987: El megalitismo en Andalucía central. El megalitismo en la Península Ibérica. Madrid, 9-29.

Ferrer, E. y MARqués, I., 1986: El cobre y el bronce en tierras malagueñas. Hom. a $L$. Siret. Madrid, $25 \uparrow-26 \dagger$

Gilman, A. and Thornes, J. B., 1985: Land-use and praeshistory in southeast Spain. London.

Gosse, G., 1941: Aljoroque, estación neolítica inicial de la provincia de Almería. Ampurias 3, 63-84.

Gusı, E., 1986: El yacimientoi de Terrera Ventura, Tabernas, y su relación con la cultura de Almería. Hom. a L. Siret. Madrid, 1986.

HaRRIson, R.J., 1977: The Bell Beaker Cultures of Spain and Portugal. Harvard Univ., Cambridge Massachusetts.

Hopf, M. und PELlicer, M., 1970: Neolithische Getreidefunde in der Höhle von Nerja (prov. Málaga). Madr. Mitt, 11. Mainz, 18-34.

JiMÉnEz, E., 1962: Excavaciones en la cueva de Ambrosio. Not. Arq. Hisp. V, Madrid, 13-48.

LeISNER, G. und V., 1943: Die Megathgräber der Ibersichen Halbinsel. I) Der Süden. Röm. Germ, Komm, Fursch., 17. Berlín.

LÓPEZ, P., 1980: Estudios de la cerámica, industria ósea y lítica de la Cueva de los Murciélagos de Albuñol (Granada). T. Pr. 37, Madrid, 164-180.

Maluquer, J., 1974: Estratigrafía prehistórica de Hornos de Segura (Jaén). Pyrenae 10, Barcelona, 43-65.

MARTín, E., 1984: Yacimientos al aire libre en la cuenca media del Benamargosa (Málaga). Col. Arq. Espacial. Teruel, 137-146.

Martínez Santa Olalla, J., 1946: Cereales y plantas de la cultura iberosahariana en Almizaraque (Almería). Cuad. Hist. Primitiva l, 35 y ss.

MEndozA, A. y otros, 1975: El poblado del Cerro de Los Castellones (Laborcillas, Granada). XIII Cong. Nac. Arq., Zaragoza, 315-322.

Margelina, C., 1941: La estación arqueológica de Montefrío (Granada), l, Los dólmenes. Bol. Sem. Arte y Arq., VIII, Valladolid, 33-106.

Molina, F., 1983: Prehistoria de Granada. Historia de Granada. Granada, 1-131.

Molina Fa.JARDO, F. y CAPEL, J., 1975: Un corte estratigráfico en el poblado campaniforme de Torre Cardela (Granada). XIII Congr. Nac. Arq. Zaragoza, 411-416.

MuIÑoz, A.M., 1986: El neolítico y los comienzos del cobre en el Sureste. Hom. a L. Siret. Madrid, 152 y ss.

Muñoz, A.M., 1987: Problemas metodológicos del neolítico del sureste de España. Coll Montepellier (1983), 627 y ss.

NavarRete, M.S., 1976: La cultura de las cuevas con cerámica decorada en Andalucia Oriental. Granada.

Navarrete, M.S., 1986: Las comunidades neolíticas en la Alta Andalucía. Hom. a L. Siret, 109-129. 
Navarrete, M.S. y CaPel, J., 1977: La cueva del Agua de Prado Negro (Iznalloz, Granada). C.P.U. Granada, 2, 18 y ss.

NOCETE, F., 1984: Elementos para un estudio del patrón de asentamiento en las campiñas occidentales del Alto Guadalquivir durante la edad del cobre. Col. Arq. Espacial, 3, Terual, 91103.

OLARIA, C., 1975: Excavaciones en la necrópolis megalítica de los Churuletes (Purchena, Almería). XIV Congr. Nac. Arq., Zaragoza, 439-452.

Pellicer, M., 1963: Estratigrafía prehistórica de la Cueva de Nerja (Málaga), Mem. Exc. Arq. España 16.

Pellicen, M., 1964: Actividades de la Delegación de Zona de la Provincia de Granada durante los años 1953 - 1962. Not. Arq. Hisp. 6. Madrid, 304-350.

Pellicer, M., 1964: El neolítico y el bronce de la Cueva de la Carigüela de Piñar (Granada). Tr. Preh. XV, Madrid.

Pellicer, M., 1986: Neolítico. Calcolítico. En Historia de España. Gredos, Madrid, 1, 151-264.

Pellicer, M., 1987: El neolítico de la Cueva de Nerja (Málaga). Coll, Intern. premieres Comm. Pays. Medit. Occid. Montepellier, 639-643.

Pellicer, M. y Acosta, P., 1986: Neolítico y Calcolítico de la Cueva de Nerja. Trab. Cueva Nerja 1, Málaga, 339-450.

Ramos, J. y MARTín, E., 1987: Tajo de Gomer (Ríogordo, Málaga). Un asentamiento neolítico al aire libre en el Alto Vélez. Publ. Arq. Ayunt. Velez Málaga, 2.

RonRiguez, G., 1982: La Cueva del Nacimiento. Pontones-Santiago-Prov. Jaén (España). Coll. Néol. Anc. Montepellier (1981), 237-250.

Ruiz, A. y otros, 1986: La edad del cobre y la argarización en tierras gienenses. Hom. a L. Siret. Madrid. 271-286.

SaEz, L. y MARTínez, G. 1981: El yacimiento neolítico al aire libre de la Molaina (Pinos Puente, Granada). Cuad. Preh. Un. Granada, 6, 17-34.

SARRion I, 1980: Valdecuevas. Estación mesoneolítica en la Sierra de Cazorla (Jaén). Saguntum 15, 23-56.

SCHÜLE, W., 1980: Orce und Galera. Madr. Beitr. Mainz.

SChüle, W. y Pellicer, M., 1966: El Cerro de la Virgen, Orce (Granada). Exc. Arq. España, 46.

SIRET, E. y L., 1890: Las primeras edades del metal en el Sudeste de España. Barcelona.

SUÁREZ, A. y otros, 1986: Aportaciones al estudio de la edad del cobre en la provincia de Almería. Análisis de la distribución de yacimientos. Hom. a L. Siret. Madrid, 196-207.

TORRE, F. DE LA y SAEZ, L., 1986: Nuevas excavaciones en el yacimiento de la edad del cobre de El Malagón. Hom. a L. Siret. Madrid, 221-226. 